\title{
The bovine neutrophil: Structure and function in blood and milk
}

\author{
Max J. PAAPE ${ }^{a *}$, Douglas D. BANNERMAN ${ }^{\mathrm{a}}$, Xin ZHAO ${ }^{\mathrm{b}}$, Jai-Wei LeE ${ }^{\mathrm{b}}$ \\ a Immunology and Disease Resistance Laboratory, USDA-ARS, Beltsville, MD, 20705, USA \\ ${ }^{\mathrm{b}}$ Department of Animal Science, McGill University, Ste-Anne-de-Bellevue, Quebec, Canada
}

(Received 9 October 2002; accepted 24 April 2003)

\begin{abstract}
Migration of polymorphonuclear neutrophil leukocytes (PMN) into the mammary gland provide the first line of defense against invading mastitis pathogens. Bacteria release potent toxins that activate white blood cells and epithelial cells in the mammary gland to secrete cytokines that recruit PMN that function as phagocytes at the site of infection. While freshly migrated PMN are active phagocytes, continued exposure of PMN to inhibitory factors in milk such as fat globules and casein, leads to altered PMN morphology and reduced phagocytosis. In the course of phagocytosing and destroying invading pathogens, PMN release chemicals that not only kill the pathogens but that also cause injury to the delicate lining of the mammary gland. This will result in permanent scarring and reduced numbers of milk secretory cells. The life span of PMN is limited by the onset of apoptosis. To minimize damage to mammary tissue, PMN undergo a specialized process of programmed cell death known as apoptosis. Macrophages quickly engulf and phagocytose apoptotic PMN, thereby minimizing the release of PMN granular contents that are damaging to tissue. The PMN possess an array of cell surface receptors that allow them to adhere and migrate through endothelium and to recognize and phagocytose bacteria. One receptor found on phagocytes that is receiving considerable attention in the control of infections by Gram-negative bacteria is CD14. Binding of lipopolysaccharide (LPS) to membrane bound CD14 causes release of tumor necrosis factor- $\alpha$ and sepsis. Binding of LPS to soluble CD14 shed from CD14-bearing cells results in neutralization of LPS and rapid recruitment of PMN to the site of infection. Recent advances in the fields of genomics and proteomics should greatly enhance our understanding of the PMN role in controlling intramammary infections in ruminants. Further, manipulation of PMN, through either recombinant proteins such as soluble CD14 that enhance PMN response or agents that mediate PMN apoptosis, may serve as novel therapeutics for the treatment of mastitis.
\end{abstract}

neutrophil / chemotaxis / phagocytosis / oxidative burst / apoptosis / mastitis

Table of contents

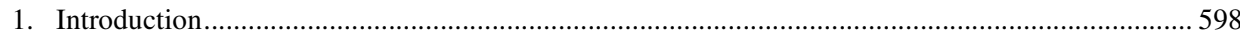

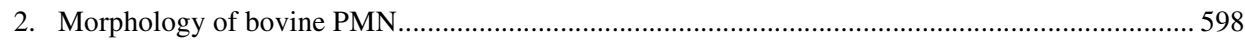

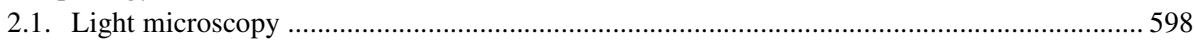

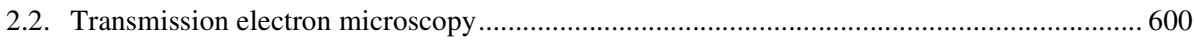

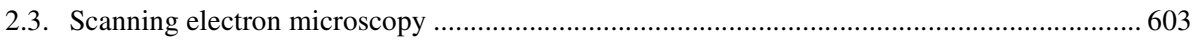

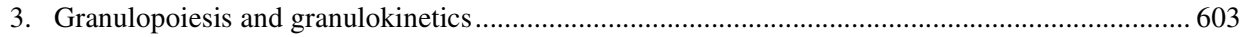

\footnotetext{
* Corresponding author: mpaape@ anri.barc.usda.gov
} 


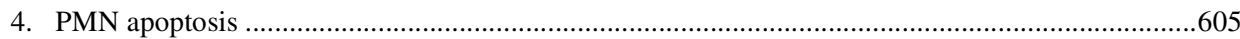

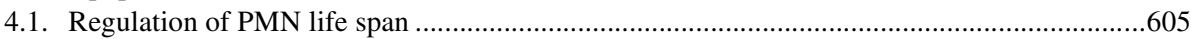

4.2. Influence of inflammatory mediators ................................................................................606

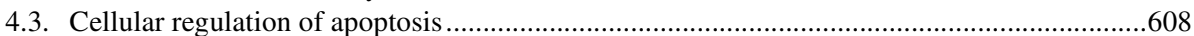

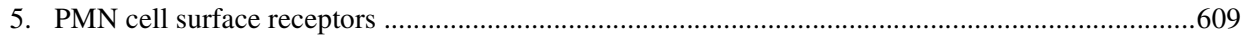

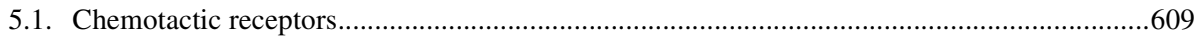

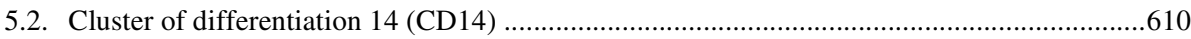

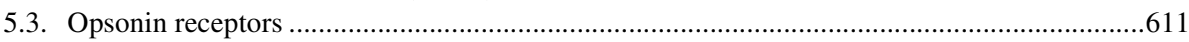

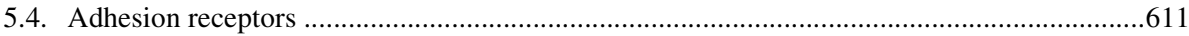

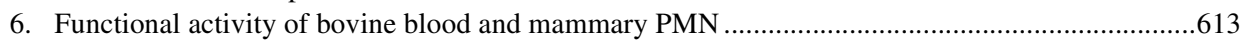

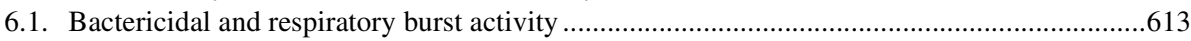

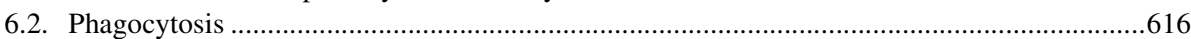

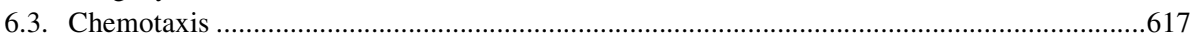

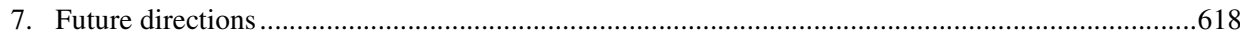

\section{INTRODUCTION}

Polymorphonuclear neutrophil leukocytes (PMN) form the first line of cellular defense against invading pathogens. The PMN is characterized by a polymorphicsegmented nucleus, numerous cytoplasmic granules that provide constituents for killing bacteria, large stores of glycogen for energy and a highly convoluted surface that is used for phagocytosis of bacteria and formation of intracellular phagocytic vacuoles. Numerous receptors are present on the PMN surface. Some receptors are used to detect chemoattractants that allow PMN to migrate toward areas of inflammation. Adhesion receptors provide the feet for moving across, through endothelium and into sites of infection. Other receptors bind immunoglobulins and complement components that allow PMN to initiate phagocytic and bactericidal functions. Another group of receptors bind bacterial toxins and cytokines that initiate protein tyrosine phosphorylation for synthesis and expression of functionally important cell surface receptors that are used in host defense. A striking change in morphology occurs when PMN leave blood and enter milk. In milk, PMN ingest milk fat globules and casein that result in large intracellular membrane bound vacuoles. Internalization of cell membrane leads to loss of pseudopodia and cell rounding. Cytoplasmic gran- ules migrate and fuse to vacuoles forming phagolysosomes. This loss of membrane and cytoplasmic granules results in diminishment of PMN phagocytic and bactericidal activities and compromises intramammary defense. Intramammary defense against invading microorganisms is dependent on an increase in number of PMN recruited to the mammary gland, whereas, resolution is dependent on diminishment in elevated numbers of PMN. Both of these processes are mediated, in part, by changes in PMN life span and inhibition and/or acceleration of PMN apoptosis.

\section{MORPHOLOGY OF BOVINE PMN}

\subsection{Light microscopy}

When PMN in Wright stained blood smears are examined by light microscopy the cytoplasm is clear and contain numerous light pink cytoplasmic granules. Mature PMN contain a polymorphic segmented nucleus (Fig. 1A). The nuclear lobes are connected by short filaments. In healthy cows immature PMN are seldom seen in blood (Tab. I) [126]. Immature PMN (myelocyte, metamyelocyte and band) are normally found only in bone marrow. Band PMN are about the size of a mature PMN with clear cytoplasm containing light pink granules (Fig. 1B). The 

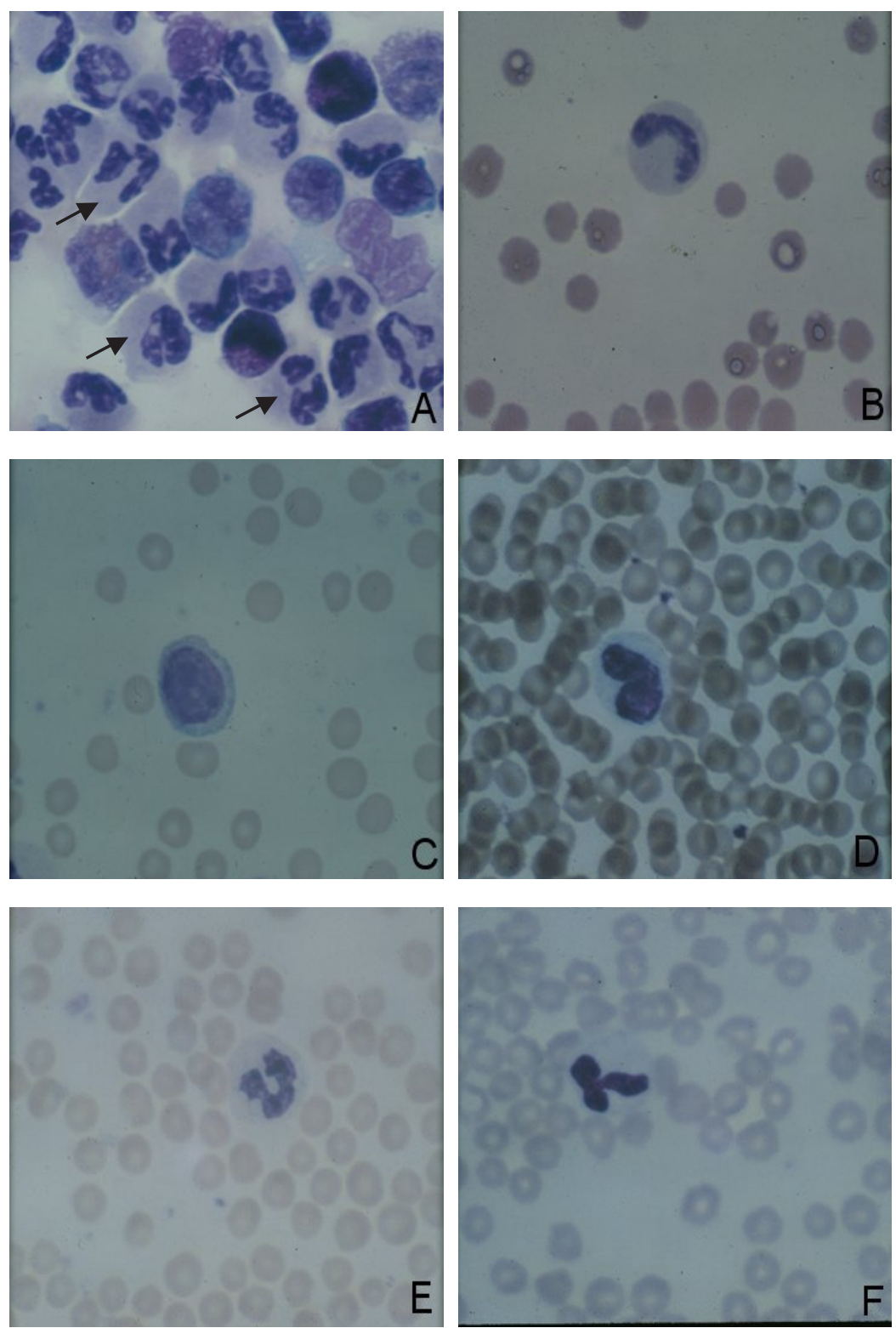

Figure 1. Light micrographs of normal mature bovine polymorphonuclear neutrophil leukocytes $(\mathrm{PMN})$ and immature and abnormal bovine PMN commonly found in peripheral blood smears after intramammary injection of Escherichia coli endotoxin (Wright's stain, $\times 1250$ ). (A) Cytospin preparation of isolated blood leukocytes (85\% PMN). Mature PMN contain the characteristic polymorphic segmented nucleus (arrows). (B) Immature blood PMN (band) with typical horseshoe shaped nucleus. (C) Immature blood PMN (myelocyte) with typical large spherical nucleus. (D) Immature blood PMN (metamyelocyte) with typical kidney-bean shaped nucleus. (E) Endotoxin induced abnormal PMN showing evidence of delayed maturation. (F) Endotoxin induced apoptotic PMN with bizarre nuclear pattern. 
Table I. Circulating leukocyte and polymorphonuclear neutrophil leukocyte (PMN) count and milk somatic cell count (MSCC) after intramammary injection of $0.5 \mathrm{mg}$ Escherichia coli endotoxin ${ }^{\mathrm{a}}$ (adapted from [126]).

\begin{tabular}{lccccc}
\hline & & \multicolumn{3}{c}{ PMN (per mm ${ }^{3}$ in blood) } & \\
\cline { 3 - 5 } $\begin{array}{l}\text { Hours relative } \\
\text { to injection }\end{array}$ & $\begin{array}{l}\text { Circulating } \\
\text { leukocytes }\end{array}$ & Juvenile & Band & Segmented & MSCC $\left(\times 10^{6} / \mathrm{mL}\right)$ \\
\hline 0 & 6126 & 0 & 61 & 2389 & 0.06 \\
1 & 5558 & 0 & 30 & 2445 & 0.05 \\
2 & 4513 & 0 & 23 & 1625 & 0.02 \\
4 & 2295 & 103 & 115 & 356 & 1.72 \\
6 & 1958 & 176 & 235 & 284 & 8.49 \\
8 & 2704 & 406 & 379 & 662 & 37.26 \\
10 & 3669 & 532 & 807 & 660 & 28.94 \\
12 & 5226 & 967 & 653 & 993 & 28.31 \\
18 & 6434 & 1287 & 804 & 1544 & 53.78 \\
72 & 8342 & 167 & 417 & 3503 & 19.71 \\
168 & 6463 & & & & 0.15 \\
Significance & $P<0.01$ & $P<0.01$ & $P<0.01$ & $P<0.01$ & $P<0.01$ \\
level & & & & & \\
\hline E & & & & & \\
\hline
\end{tabular}

${ }^{\mathrm{a}}$ Each value represents the mean of 4 cows. ${ }^{\mathrm{b}}$ Includes metamyelocytes and myelocytes.

nucleus is in the shape of a horseshoe and is non-segmented. To be classified as a band, at least $60 \%$ of the sides of the nucleus wall must be parallel. Myelocytes contain a round nucleus and faint blue cytoplasm (Fig. 1C). To the untrained eye, these cells could be mistaken for lymphocytes. However, myelocytes contain more cytoplasm and the nucleus is devoid of plaqued chromatin. Metamyelocytes also contain faint blue cytoplasm and the nucleus is kidney-bean in shape (Fig. 1D).

During acute coliform mastitis induced by intramammary injection of Escherichia coli endotoxin, immature PMN are found in blood and is referred to as a "left shift" (Tab. I) [126]. By $18 \mathrm{~h}$ post injection, 12\% of the circulating leukocytes are band PMN and 20\% are juvenile PMN (includes myelocytes and metamyelocytes). During the left shift many abnormal PMN are observed. Toxemia delays segmentation of PMN and nuclei of these PMN are horseshoe shaped, containing densely clumped chromatin similar to that found in normal mature segmented PMN (Fig. 1E). Another sign of toxemia is the appearance of apoptotic PMN with bizarre nuclear patterns (Fig. 1F).

\subsection{Transmission electron microscopy}

The fine structure of circulating and mammary bovine PMN has been carefully defined [125, 131]. The most prominent characteristic is the multilobulated nucleus (Fig. 2A). The multilobulated nucleus is important because it allows PMN to line up its nuclear lobes in a straight line, allowing for rapid migration between endothelial cells. Macrophages on the other hand have a large horseshoe shaped nucleus that makes migration between endothelial cells difficult. Thus, PMN are the first newly migrated phagocytic cells to arrive at an infection site. Within the cytoplasm are isles of glycogen and numerous bactericidal granules that are used by PMN in 


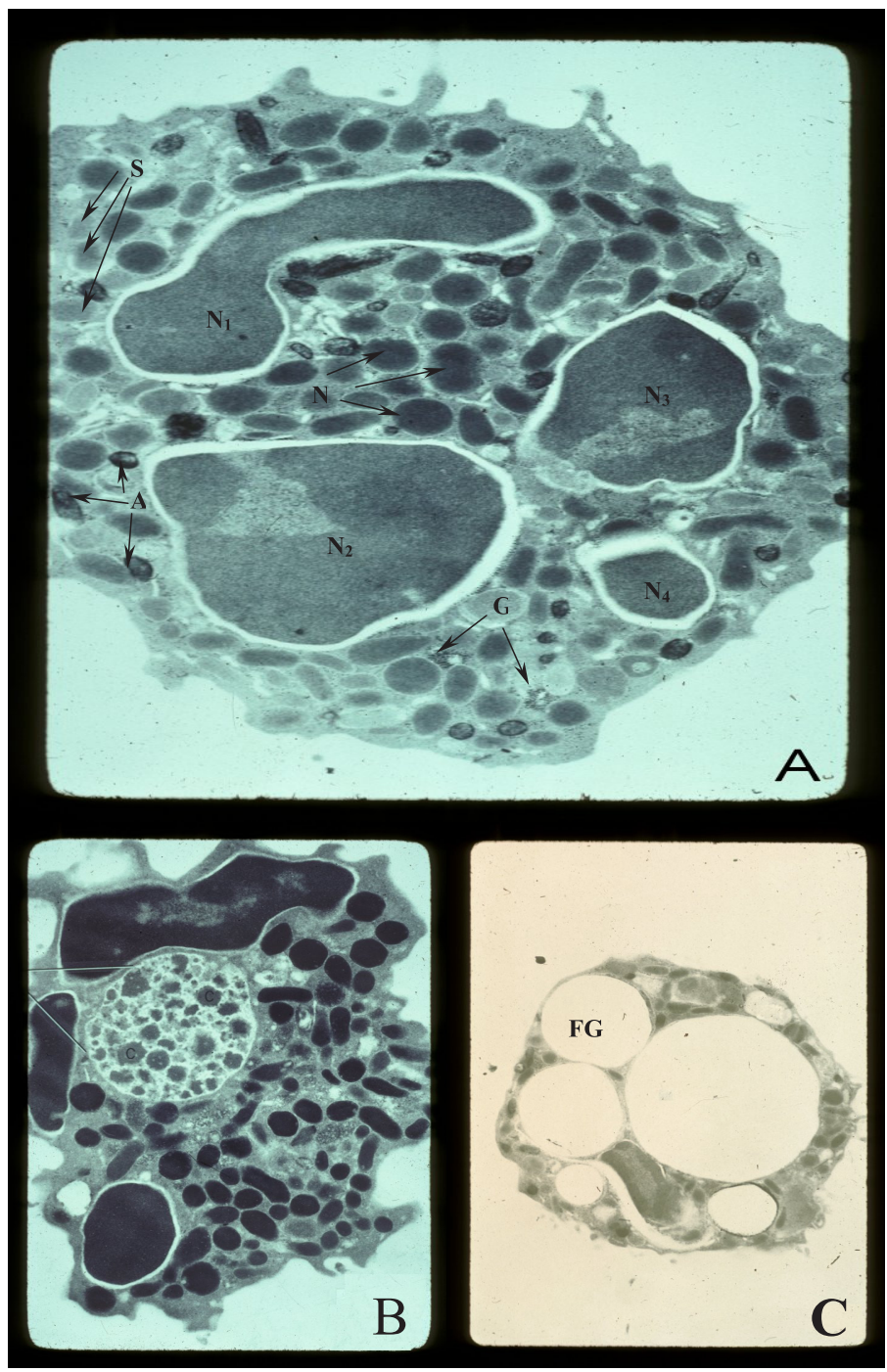

Figure 2. Transmission electron micrographs of bovine polymorphonuclear neutrophil leukocytes (PMN) isolated from blood and milk. (A) The blood PMN contain portions of a multilobed nucleus $\left(\mathrm{N}^{1}\right.$ to $\left.\mathrm{N}^{4}\right)$, glycogen granules $(\mathrm{G})$, specific granules $(\mathrm{S})$, peroxidase negative large "novel" granules $(\mathrm{N})$, and peroxidase positive azurophilic granules $(\mathrm{A})$. The azurophilic granules are stained more intensely than the specific or "novel" granules because the leukocyte was incubated with diaminobenzidine and hydrogen peroxide. As a result, an electron-dense product, indicative of peroxidatic activity, has formed in azurophilic granules, $\times 15000$. (B) A milk PMN with a large phagocytic vacuole (arrow) containing numerous previously phagocytosed casein micelles, $\times 11250$. (C) The surface of this milk PMN is smooth and spherical due to loss of pseudopods caused by internalization of membrane material that now forms the phagosomes that contain milk fat globules $(\mathrm{FG}), \times 5300$. 
killing bacteria. Like other species, bovine PMN contain azurophilic and specific (secondary) granules. Azurophilic or primary granule is the first granule to appear during the progranulocyte stage of granulopoiesis $[13,14,83]$. They are large electron-dense granules. These granules are peroxidasepositive and when incubated with diaminobenzidine and hydrogen peroxide, an electron-dense product is formed, indicative of peroxidatic activity (Fig. 2A). The most important antibacterial mechanism derived from azurophilic granules is peroxidase [94]. Peroxidase in the presence of hydrogen peroxide and halide ions kill bacteria. Lysozyme, an important bactericidal component found in azurophilic granules of other species, is present in very low concentrations in bovine azurophilic granules [145]. Secondary or specific granules appear during the myleocyte stage $[14,83]$. These granules are peroxidase-negative and not as electron dense as azurophilic granules. The formation of azurophilic granules stops once synthesis of secondary granules begins. Thus, secondary granules outnumber azurophilic granules in mature PMN. A third "novel" large peroxidasenegative granule has been identified in cows, goats and sheep [54]. These granules are larger than azurophilic and secondary granules, first appear in myelocytes and are the predominant granules in mature bovine PMN [12]. These granules contain the majority of the antimicrobial protein activity [53]. They contain lactoferrin and a group of highly cationic proteins termed bactenecins. Two bactenecins with approximate molecular weights of 7000 and 5000 called Bac7 and Bac 5 have been identified [50]. Both are highly cationic polypeptides that permeabilize the outer and inner membranes of Escherichia coli. "Novel" granules are also the exclusive store of powerful oxygen-independent bactericidal compounds called $\beta$-defensins. Defensins are cysteine and arginine rich peptides, containing 3842 residues, and display bactericidal activity against many Gram-positive, Gramnegative, and anaerobic bacteria, fungi and viruses [153]. In milk from infected quarters where oxygen tension is low, oxygen independent mechanisms of killing bacteria may be more important. Three $\beta$-defensins have been cloned, expressed, characterized and shown to exist as fully processed peptides within "novel" large granules [191]. A synthetic defensin molecule called dodecapeptide was recently synthesized [144]. Its structure mimics the structure of large defensins found in "novel" granules and appear to have microbicidal activity similar to defensin molecules.

During mastitis, lactoferrin from "novel" and secondary granules is released during migration into the mammary gland as a consequence of PMN degranulation. Inflammatory mediators like platelet-activating factor (PAF) and interleukin (IL)-8 will also cause release of lactoferrin from bovine PMN [167]. The release of lactoferrin at sites of infection is important because lactoferrin has a strong affinity for iron and makes it unavailable to Gram-negative bacteria that require it for growth. Lactoferrin also has a negative feed-back effect on granulopoiesis thus controlling over production of PMN during acute infection of the mammary gland [122]. The inflammatory mediators PAF and tumor necrosis factor (TNF) induce an increase in size of bovine PMN [108], slow diapedesis of PMN through the microvasculature of the mammary gland, and regulate movement of PMN to the infection site. Alkaline phosphatase is also present in secondary granules [13].

Examination of PMN isolated from milk reveals the presence of phagocytosed casein micelles, fat globules and fat globule membrane material (Figs. 2B and 2C) [125]. The predominant cytoplasmic granule in milk PMN appear to be dense azurophilic granules. Milk PMN have reduced numbers of secondary and "novel" granules compared to blood PMN. Secondary and "novel" granules are the first granules to be released into phagosomes and are extruded from PMN in greater 
number during diapedesis into milk than are azurophilic granules [13, 83]. Glycogen particles are also present throughout the cytoplasm of milk PMN.

\subsection{Scanning electron microscopy}

Examination of leukocytes isolated from blood (53\% PMN) reveals a homogeneous population of spherical leukocytes with 95\% containing numerous pseudopodia protruding from the cell, creating infoldings or pockets (Fig. 3A) [132]. Presence of these protrusions add considerably to the surface area of PMN. PMN lack ability
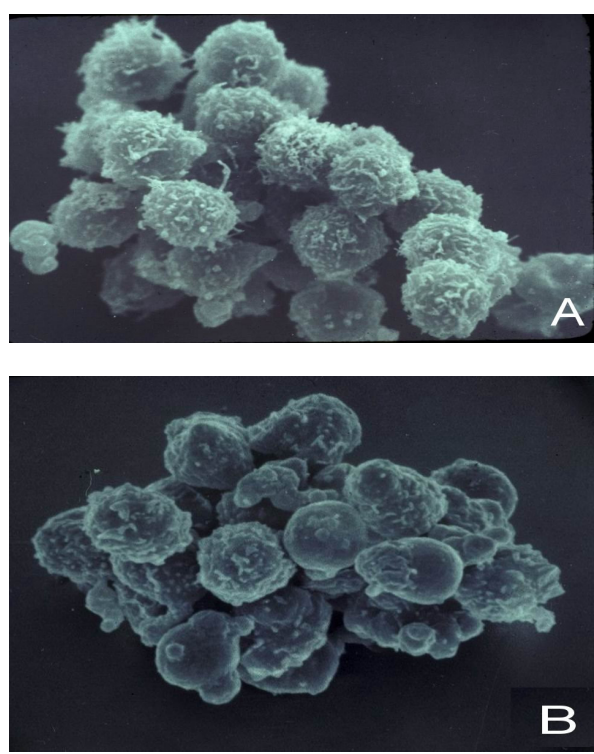

Figure 3. Scanning electron micrographs of polymorphonuclear neutrophil leukocytes (PMN) isolated from blood and milk. (A) Leukocytes (53\% PMN) were isolated from blood. About $98 \%$ of these cells are spherical and have a highly convoluted cell membrane that forms protruding pseudopods, $\times 2500$. (B) Leukocytes (98\% PMN) isolated from milk after irritation of the mammary gland with saline containing $0.1 \%$ oyster glycogen. Only $37 \%$ of these cells exhibit the extensive pseudopod formation that characterize leukocytes from blood, $\times 2500$. to regenerate plasma membrane, therefore, these protrusions give PMN an extensive plasma membrane surface area. This increased surface area is crucial to phagocytic function of PMN because extensive areas of plasma membrane are internalized during phagocytosis to form phagosomes. Examination of leukocytes isolated from milk (97\% PMN) reveals a heterogeneous population of leukocytes of varying shapes with only $37 \%$ of the cells exhibiting extensive pseudopod formation (Fig. 3B). Loss of pseudopodia is due to phagocytosis of milk fat globules and casein, and internalization of plasma membrane to form phagosomes containing fat globules and casein.

\section{GRANULOPOIESIS AND GRANULOKINETICS}

The three phases in the life span of PMN are the intramedullary, circulatory and tissue phases [83]. The intramedullary phase consists of the proliferative, maturative and storage pools of PMN in bone marrow. The proliferative pool consists of myeloblasts, promyelocytes and myelocytes. The maturative pool consists of metamyelocytes and band cells. The storage or reserve pool consist of mature PMN. Limited studies have been performed on granulopoiesis in the bovine. Myelopoiesis was studied using autoradiography in calves [174]. In normal calves the mean time for production of labeled PMN is 5.77 days. The mean time of arrival of labeled PMN in blood is 7.01 days. Mature PMN leave the hematopoietic compartment of bone marrow and enter the vascular sinus by traveling in migration channels through the endothelial cell, adjacent to the intracellular endothelial junction. The half-life of $\mathrm{PMN}$ in the circulation is $8.9 \mathrm{~h}$ [30]. The liver, lungs and spleen serve as important removal sites for PMN [83].

Unlike many animal species where PMN comprise the majority of the leukocytes in blood, bovine PMN make up only $25 \%$ of the total leukocyte count [83]. 
Table II. Plasma corticosteroid and circulation leukocyte and polymorphonuclear neutrophil leukocyte (PMN) response following intravenous injection of 200 IU ACTH (adapted from [129]).

\begin{tabular}{lccc}
\hline $\begin{array}{l}\text { Hours relative } \\
\text { to injection }\end{array}$ & $\begin{array}{c}\text { Corticosteroid } \\
(\mathrm{ng} / \mathrm{mL} \text { plasma })\end{array}$ & $\begin{array}{c}\text { Leukocytes } \\
\left(\times 10^{3} / \mathrm{mm}^{3}\right)\end{array}$ & $\begin{array}{c}\text { PMN } \\
\left(\times 10^{3} / \mathrm{mm}^{3}\right)\end{array}$ \\
\hline-1 & 3 & 7.5 & 3.3 \\
0 & 3 & 7.7 & 3.1 \\
0.25 & $15^{*}$ & 7.5 & 3.2 \\
0.50 & $45^{*}$ & 7.5 & 3.3 \\
1 & $38^{*}$ & 7.4 & 3.1 \\
2 & & $9.3^{*}$ & $4.3^{*}$ \\
4 & $34^{*}$ & $9.3^{*}$ & $5.0^{*}$ \\
6 & $12^{*}$ & $9.7^{*}$ & $5.7^{*}$ \\
8 & & $9.7^{*}$ & $5.4^{*}$ \\
12 & & $9.4^{*}$ & $4.6^{*}$ \\
24 & & $8.2^{*}$ & 3.6 \\
48 & 5 & 7.2 & 3.1 \\
\hline
\end{tabular}

* Significantly different from basal $(-1,0 \mathrm{~h})(P<0.01)$.

However, when one considers the size and blood volume ( $8 \%$ body weight) of mature lactating Holstein cows, a potential pool of over 100 billion circulating mature PMN are present [131]. In addition to circulating PMN is a marginal pool of mature PMN adhering to walls of blood vessels [83]. The number of PMN in the various storage compartments can be examined by intravenous injection of adrenocorticotropin $(\mathrm{ACTH})$, lipopolysaccharide (LPS) and intramammary injection of LPS. After injection of $250 \mathrm{IU}$ of ACTH circulating PMN increase $60 \%$ (68 billion) [127]. In a study that examined the kinetics of the glucocorticosteroid and PMN response following injection of $\mathrm{ACTH}$, it was found that glucocorticosteroids increase within 15 min after injection of $200 \mathrm{IU}$ of ACTH (Tab. II) [129]. However, it took two hours for the concentration of circulating PMN to increase and the increase accounted for almost all of the increase in circulating leukocytes. Immature PMN were not observed indicating that the increase in mature PMN came from the marginal pool of mature
PMN adhering to walls of blood vessels. Glucocorticosteriods are known to reduce adhesion of PMN to the surface of endothelial cells, mediated by shedding of cell surface L-selectin (CD62L) and CD18 adhesion receptors [26]. Intravenous injection of $100 \mu \mathrm{g}$ of LPS into lactating cows reduces concentration of circulating leukocytes by $6 \mathrm{~h}$ postinjection (Tab. III) [85]. This is accompanied by an increase in band PMN and a decrease in segmented PMN. A transient rebound in PMN is observed at $30 \mathrm{~h}$ post injection and precedes the gradual normalization of PMN numbers in blood. Lipopolysaccharide-induced neutropenia is attributed to a variety of causes such as increased adhesiveness that leads to increased margination and sequestration of PMN into the microvasculature particularly of the lungs. Rebound neutrophilia and left shift were attributed to increased mobilization of mature and immature PMN from the bone marrow PMN pool [85].

The number of PMN storage pools that respond to an irritation in the mammary gland depends on severity of the irritation 
Table III. Circulating leukocytes and polymorphonuclear neutrophil leukocyte (PMN) response after intravenous injection of $100 \mu \mathrm{g}$ Escherichia coli endotoxin (adapted from [85]).

\begin{tabular}{|c|c|c|c|c|c|}
\hline \multirow{3}{*}{$\begin{array}{l}\text { Hours } \\
\text { post-injection }\end{array}$} & \multirow{3}{*}{$\begin{array}{c}\text { Leukocytes } \\
\left(\text { per } \mathrm{mm}^{3} \text { ) }\right.\end{array}$} & \multicolumn{4}{|c|}{ PMN } \\
\hline & & \multicolumn{2}{|c|}{ Bands } & \multicolumn{2}{|c|}{ Segmented } \\
\hline & & $\%$ & Per $\mathrm{mm}^{3}$ & $\%$ & Per $\mathrm{mm}^{3}$ \\
\hline 0 & 9996 & 1.1 & 113 & 43.0 & 4350 \\
\hline 6 & $4697^{a}$ & $11.1^{\mathrm{a}}$ & $511^{\mathrm{a}}$ & $31.6^{\mathrm{a}}$ & $1471^{\mathrm{a}}$ \\
\hline 30 & 11003 & $10.4^{\mathrm{a}}$ & $1162^{\mathrm{a}}$ & 43.9 & 4925 \\
\hline 54 & 10264 & $6.1^{\mathrm{a}}$ & $643^{a}$ & 35.8 & 3752 \\
\hline 78 & 9478 & 2.9 & 285 & 33.7 & 3359 \\
\hline 150 & 9266 & 2.1 & 211 & 35.1 & 3401 \\
\hline
\end{tabular}

${ }^{a}$ Significantly different from $0 \mathrm{~h}(P<0.05)$.

and strength of the chemotactic agent. Intramammary injection of saline containing $0.1 \%$ oyster glycogen into two mammary quarters results in a milk leukocytosis of $4.2 \times 10^{6} / \mathrm{mL}$ (Tab. IV) [130]. Cytological examination of milk PMN indicates that $98 \%$ of the cells were mature. This indicates that the number of mature PMN in circulating and marginal pools is large enough to mobilize mature PMN into milk. In contrast, injection of $0.5 \mathrm{mg}$ of $E$. coli endotoxin induces a much greater chemotactic response that results in an excess of $53.78 \times 10^{6} / \mathrm{mL}$ of milk, depletes all three storage pools of mature PMN and causes release of immature PMN from bone marrow (Tab. I) [126].

\section{PMN APOPTOSIS}

\subsection{Regulation of PMN life span}

Host recovery from bacteria-induced mastitis is balanced by elimination of the infectious agent and resolution of the elicited inflammatory response. PMN are an essential component of the immune system that serve as the primary defense against bacterial infection of the bovine mammary
Table IV. Circulating leukocyte and polymorphonuclear neutrophil leukocyte (PMN) count and milk somatic cell count (MSCC) after intramammary injection of $0.1 \%$ oyster glycogen $^{\mathrm{a}}$ (adapted from [130]).

\begin{tabular}{lcc}
\hline $\begin{array}{l}\text { Parameter } \\
\text { measured }\end{array}$ & $\begin{array}{c}\text { Before } \\
0 \mathrm{~h}\end{array}$ & $\begin{array}{c}\text { After } \\
11 \mathrm{~h}\end{array}$ \\
\hline $\begin{array}{l}\text { Total circulating } \\
\text { leukocytes }\left(\text { per } \mathrm{mm}^{3}\right)\end{array}$ & 7106 & 6754 \\
PMN (per $\left.\mathrm{mm}^{3}\right)$ & & \\
Segmented & 2533 & 2079 \\
Band & 0 & 40 \\
Juvenile & 40 & 0 \\
MSCC $\left(\times 10^{6} / \mathrm{mL}\right)$ & 0.06 & 4.17 \\
\hline${ }^{a}$ Each value represents the mean from 3 animals.
\end{tabular}

gland. Although PMN provide a beneficial effect by eliminating the infectious agent, prolonged exposure of mammary tissue to PMN results in injury to secretory epithelium [29]. One mechanism by which this may occur is through release of toxic oxygen radicals and proteases, agents which are both bactericidal and cytotoxic to host tissue [96, 181]. Prolonged inflammation resulting in injury to the mammary 
secretory epithelium results in scarring and leads to a permanent decrease in milk production [165]. Therefore, rapid elimination of PMN by macrophages following bacterial neutralization is essential to minimizing inflammatory-derived injury to the host.

There is compelling evidence that PMN apoptosis plays a key role in resolution of the inflammatory response in both humans $[63,81,152]$ and cows $[35,158]$. Apoptosis is a form of cell death morphologically characterized by chromatin condensation, nuclear fragmentation, cell shrinkage and blebbing of the plasma membrane [58, 146]. The end result of apoptosis is fragmentation of PMN into small membranebound bodies that are quickly cleared by phagocytotic cells [38, 152, 157]. In contrast, necrotic cell death is characterized by cell swelling and lysis. The loss of membrane integrity of necrotic cells is accompanied by release of cellular contents that injure neighboring cells and trigger an inflammatory response [58, 146].

Under physiological conditions, bovine PMN have a relatively short half-life [30] and spontaneously undergo apoptosis [48]. Differences in developmental stages, however, influence rate of spontaneous PMN apoptosis. PMN isolated from human umbilical cord blood exhibit decreased spontaneous apoptosis and impaired sensitivity to apoptosis-inducing agents, such as anti-Fas $\operatorname{IgM}$ and cycloheximide, compared with PMN derived from adults [6]. In cows, PMN apoptosis is influenced by stage of lactation. In one study, blood was obtained from early lactating ( $13 \pm 6$ days after parturition) and mid-lactating (170 \pm 26 days after parturition) cows and subsequently incubated for four hours to induce apoptosis [175]. PMN isolated from the blood of early lactating cows demonstrated a higher rate of apoptosis than PMN derived from mid-lactating cows. Interestingly, PMN isolated from early lactating cows also display impaired function [89]. Further, onset of apoptosis has been similarly reported to downregulate bovine PMN phagocytic and respiratory burst activity [176]. One may speculate that increased susceptibility of bovine PMN to apoptosis during the period immediately following parturition contributes to impaired PMN function [89] and increased severity of mastitis observed during this period [27].

\subsection{Influence of inflammatory mediators}

During infection, pro-inflammatory cytokines and bacterial products may delay or accelerate onset of PMN apoptosis [4]. Several cytokines that are upregulated during inflammation, including IL- $1_{\beta}$ [37], IL-2 [138], IL-6 [21], IL-8 [92, 102], IL-15 [56], IFN- $\gamma$ [37], G-CSF [37], and GM-CSF [37, 97], reportedly prolong human PMN survival. Another pro-inflammatory cytokine that is upregulated at the onset of mastitis, TNF- $\alpha[75,160]$, induces apoptosis in both human- $[61,190]$ and bovine-derived PMN [176]. The signaling pathway by which TNF- $\alpha$ induces apoptosis has been well-described [11]. TNF- $\alpha$ induces trimerization of its receptor resulting in clustering of the receptors' intracellular death domains (DD). These DD are highly conserved regions that facilitate protein-protein interaction with other DD-containing proteins, including TNF receptor-associated death domain protein (TRADD). TRADD recruits Fas-associated death domain protein (FADD), another DD-containing molecule. FADD contains another conserved binding domain, the death effector domain (DED), which is used to recruit DED-containing pro-caspase- 8 via respective interactions of each protein's DED regions. Pro-caspase- 8 is one member of a larger family of proteases that are centrally involved in mediating apoptosis. Pro-caspase- 8 has intrinsically low levels of proteolytic activity, which enables it to cleave and activate other procaspase- 8 molecules brought into close proximity following recruitment to FADD 
[116]. Activation of caspase- 8 initiates a proteolytic cascade that results in activation of downstream effector caspases, including caspase-3, and onset of apoptosis [69].

Fas (CD95)-induced apoptosis is a key regulator of the immune response. Fas contributes to deletion of activated lymphocytes and mediates T cell-induced killing of virally-infected cells $[11,33]$. The role of Fas in mediating human PMN apoptosis remains controversial. While it is clear that PMN express Fas [105], there are conflicting reports as to whether PMN express the ligand for Fas (CD95L) [23, 80, 105]. Despite the uncertainty surrounding Fas ligand (FasL) expression, several studies have demonstrated PMN sensitivity to Fasmediated apoptosis $[23,80,82,105]$. Further, cells of monocytic origin express FasL and induce PMN death in a Fas-dependent manner [23]. Thus, interaction of monocytic cells at inflamed sites would obviate the need for FasL expression on PMN. In contrast to data supporting a role for Fas signaling in regulating PMN longevity, PMN derived from Fas (lpr)- or Fas ligand (gld)-deficient mice undergo similar rates of apoptosis in vitro as those isolated from control animals [49]. These data suggest existence of a redundant pathway(s) that can mediate PMN apoptosis in the absence of Fas signaling. Although much of the research on Fas signaling has involved human and/or murine systems, a role for Fas in mediating apoptosis in the bovine has been reported [169].

Bacterial LPS is a highly pro-inflammatory molecule that is a component of the outer membrane of all Gram-negative bacteria. LPS has been reported to inhibit spontaneous PMN apoptosis [61, 95, 97, 168] and to protect against TNF- $\alpha$-induced apoptosis in human PMN [61]. Although the exact mechanism by which LPS inhibits human PMN apoptosis remains unknown, protein tyrosine phosphorylation [168] and mitogen-activated protein kinase [95] signaling have been implicated in mediating this effect. Further, LPS upregulates PMN expression of the cytoprotective protein, Mcl-1 [114].

LPS, when injected into the mammary gland, suppresses mammary but not circulating PMN apoptosis. Sladek et al., reported PMN isolated from mammary glands stimulated with LPS display a delay in reaching peak apoptosis compared with PMN obtained from saline-treated mammary glands [158]. In contrast, infusion of bovine mammary glands with LPS has been reported by Van Oostveldt et al., to have no effect on the rate of circulating PMN apoptosis [178], whereas, others have reported an actual increase [189]. The conflicting results from these experiments are difficult to interpret because the PMN assayed were isolated from distinct compartments (i.e., mammary gland versus blood). After intramammary injection of LPS there is little to no absorption of LPS into the bloodstream [75]. Thus, in the studies examining circulating PMN there likely was no direct contact of PMN with LPS, whereas, Sladek et al., probably studied direct effects of LPS on mammary PMN. Incubating bovine blood with high concentrations of LPS ( $\geq 1 \mu \mathrm{g} / \mathrm{mL})$ induces PMN apoptosis [176]. The physiological relevance of this latter finding is difficult to ascertain as these concentrations of LPS reportedly induce cell injury in a receptorindependent manner [9]. Although the data with human PMN is consistent with an antiapoptotic effect of LPS, the role of LPS in promoting or inhibiting apoptosis in bovine PMN remains less clear. Interestingly, species-dependent sensitivity to LPS-induced apoptosis has been reported for endothelial cells as well. Bovine [15] and ovine [79] endothelial cells are exquisitely sensitive to LPS-induced apoptosis, whereas, human endothelial cells are resistant to direct LPS killing [16]. The mechanism for this differential species sensitivity remains unknown.

In addition to soluble mediators of inflammation, there is evidence to suggest that the actual processes of adhesion and migration influence PMN apoptosis [55, $157,177,182]$. First, the composition of the 
extracellular matrix which PMN adhere to and migrate through alters the rate of human [55] and bovine [177] PMN apoptosis. Second, the type of cell which bovine PMN adhere to and diapedese through influences onset of PMN apoptosis [177]. Third, PMN adherence to quiescent or activated endothelium accelerates or delays, respectively, PMN apoptosis [55, 182]. Fourth, PMN isolated from rat lungs following induced transmigration demonstrate a delay in onset of spontaneous apoptosis [182]. Although the mechanism by which adhesion influence PMN apoptosis remains unclear, there is evidence to suggest a role for the $\beta-2$ integrin, CD11b, in mediating this event $[39,182]$.

\subsection{Cellular regulation of apoptosis}

The ability of a cell to commit to apoptosis is determined by both pro- and antiapoptotic signaling pathways. The Bcl-2 family of proteins play a central role in mediating these diametrically opposed processes $[2,8]$. The $\mathrm{Bcl}-2$ related proteins can be divided into pro- and anti-apoptotic members. A key mechanism by which these proteins mediate apoptosis is through regulation of mitochondrial cytochrome $\mathrm{c}$ release $[2,8]$. Cytochrome $\mathrm{c}$ is a co-factor in activation of caspase-9, the latter of which activates downstream effector caspases, including caspase-3. Pro-apoptotic Bcl-2 family members promote cytochrome c release whereas anti-apoptotic members restrict transport of cytochrome $\mathrm{c}$ out of mitochondrion. Bcl-2 family members are characterized by the presence of one or more of four distinct Bcl-2 homology $(\mathrm{BH})$ domains that facilitate proteinprotein interactions. Anti-apoptotic Bcl-2 family members exert their effect by forming heterodimers via these $\mathrm{BH}$ domains with pro-apoptotic members, and restricting ability of the latter to facilitate cytochrome c release.

Human PMN express both pro- (Bad [151], Bak [19, 151], Bax [44, 185]) and

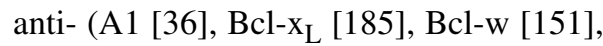
Bfl-1 [151], Mcl-1 [114, 115]) apoptotic members of the Bcl-2 family. Several lines of evidence exist to suggest that changes in relative expression of these proteins can determine whether PMN will undergo apoptosis. GM-CSF inhibition of PMN apoptosis occurs temporally with enhanced expression of the anti-apoptotic protein Mcl-1 [47, 114] and with decreased expression of the pro-apoptotic protein Bax [185]. Targeted downregulation of the expression of anti-apoptotic Mcl-1 protein [103] or pro-apoptotic Bax protein [44], enhances and delays, respectively, spontaneous PMN apoptosis. Further, spontaneous apoptosis is reportedly enhanced in PMN isolated from A1-a knockout mice relative to wildtype control PMN [62]. Finally, A1-a-deficient PMN are insensitive to LPS-induced inhibition of PMN apoptosis, suggesting a role for the anti-apoptotic A1 protein in mediating this response. Thus, relative expression of the Bcl-2 homologs serves as a rheostat to determine fate of PMN.

A hallmark of apoptosis is activation of highly specific effector proteases of the caspase family. Caspases exist as inactive zymogens (proenzymes) that are activated by proteolytic processing of the procaspase molecule in one of three ways: (1) autoactivation due to low levels of intrinsic catalytic activity; (2) transactivation by other caspases within close proximity; or (3) activation by non-caspase proteases [172]. Once activated, caspases cleave and activate other members of the caspase family leading to amplification of a proteolytic cascade. The end result is a series of proteolytic events that lead to cleavage of intracellular substrates, chromatin condensation, DNA fragmentation, and eventual cell death. Of the 14 distinct caspases identified in mammals, seven (caspases-1, 3, 4, $7,8,9,10)$ are expressed in PMN [151]. Among these seven caspases, caspase-3 and 8 have a central role in mediating PMN apoptosis. Spontaneous PMN apoptosis is temporally associated with activation of 
both of these caspases [41, 93, 140] and is attenuated by specific inhibitors of caspase-3 [140] and caspase-8 [93]. Similarly, inducible PMN apoptosis, in response to ultraviolet irradiation [51], Fas [41, 51], or TNF- $\alpha$ [190], is mediated by caspase-3 and/or caspase- 8 . Together, these data suggest a central role for caspases in regulating lifespan of PMN under physiological and pathophysiological conditions.

The requisite involvement of caspases in regulating life span of bovine PMN presents a novel target for therapeutic intervention. Because onset of apoptosis leads to functional impairment of bovine PMN [176], in vivo administration of caspase inhibitors may play an effective role in enhancing the ability of PMN to respond to intramammary infection. Further, caspase inhibitors may have the additional benefit of protecting secretory epithelium from deleterious effects of PMN-derived cytotoxic mediators produced in response to infection $[29,96]$. In support of a potential therapeutic benefit for caspase inhibitors in mastitis, two studies have shown that prevention of lymphocyte-induced apoptosis with the caspase inhibitor $\mathrm{z}-\mathrm{VAD}$ enhances survival in a murine model of sepsis [76, 77].

Although a delay in PMN apoptosis may be advantageous in early stages of infection, accelerated PMN apoptosis may be beneficial following elimination of the infectious agent. Because activated PMN and their products induce injury to bovine mammary tissue $[29,96]$, prompt elimination of PMN following infection would be expected to enhance resolution of the inflammatory response. In agreement with this hypothesis, induction of bovine PMN apoptosis with tilmicosin has been reported to prevent amplification of inflammatory injury following infection with Pasteurella haemolytica [34]. Therefore, agents that can specifically target PMN and initiate caspase activation may have a therapeutic role in resolution of mastitis and/or other inflammatory responses.

\section{PMN CELL SURFACE RECEPTORS}

\subsection{Chemotactic receptors}

Directional migration of PMN along a chemoattractant gradient is essential for delivery of PMN to an infection site. During mastitis, inflammatory chemoattractants guide PMN toward foci of infection. Important chemoattractants for recruiting bovine PMN are complement components $\mathrm{C} 5 \mathrm{a}$ and C3a, LPS, IL-1, IL-2 and IL-8 [31, 40, 42, 59, 60, 99, 171]. These chemoattractants bind to specific receptors on the PMN plasma membrane. Interleukin- 8 plays a role in not only chemotaxis but in inducing release of alkaline phosphatase from secondary granules and production of reactive oxygen species by PMN during chemotaxis $[52,66,163]$. Both non-mastitic and mastitic mammary secretions exhibit chemotactic activity [17]. However, chemotactic activity in mastitic secretions is blocked by anti-IL-8 monoclonal antibodies (MAB). This indicates that IL-8 plays a major role in PMN recruitment during mastitis and is not involved in chemotaxis of PMN in non-mastitic mammary glands. Bovine C5 $\mathrm{a}^{\text {desArg }}$ has been purified from blood serum. MAB and an ELISA have been produced for measurement of bovine $\mathrm{C} 5 \mathrm{a} /$ C5a $\mathrm{a}^{\text {desArg }}$ [142]. Low concentrations of $\mathrm{C} 5 \mathrm{a} / \mathrm{C} \mathrm{a}^{\text {desArg }}$ are present in normal milk $(0.12 \mathrm{ng} / \mathrm{mL})$ and high concentrations are found in milk collected after LPS induced mastitis $(6.5 \mathrm{ng} / \mathrm{mL})$. The C5a in normal milk may contribute to chemokinetic activity of non-mastitic milk. In vitro, purified $\mathrm{C} 5 \mathrm{a} / \mathrm{C} \mathrm{a}^{\text {desArg }}$ induce migration of PMN through a multilayered culture system [161]. Anti-bovine C5a desArg MAB blocks diapedesis induced by purified C5a but not diapedesis induced by zymosan or LPS activated fetal bovine serum. This suggests that factors other than $\mathrm{C} 5 \mathrm{a}$, possibly $\mathrm{C} 3 \mathrm{a}$, were responsible for inducing chemotaxis. Escherichia coli endotoxin alone does not induce in vitro chemotaxis of bovine PMN 


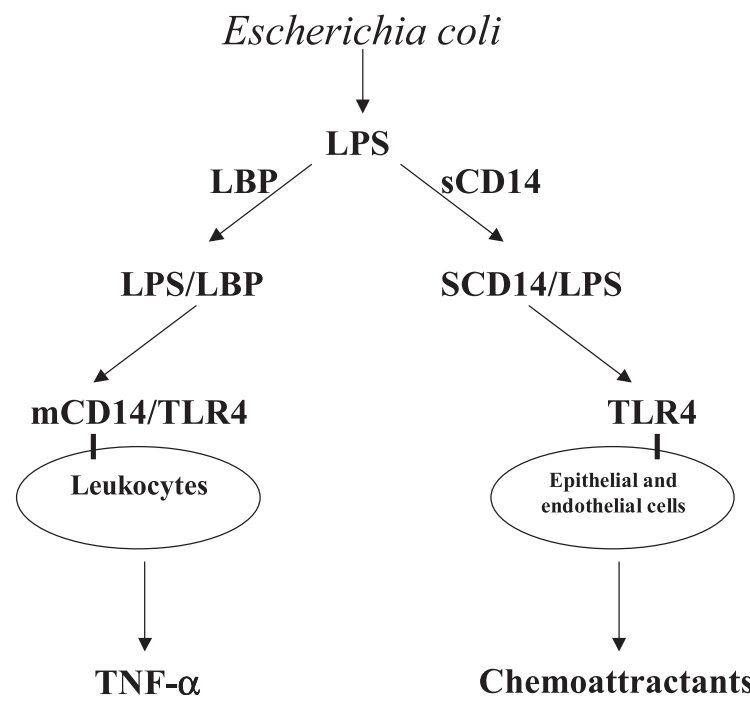

Figure 4. Binding of the LPS-binding protein/LPS complex to mCD14 on monocytes and macrophages causes release of TNF- $\alpha$, and binding of the sCD14/LPS complex to Toll-4 receptors on endothelial and epithelial cells causes release of chemoattractants.
[60], and recruitment of PMN associated with LPS occurs through activation of complement with production of $\mathrm{C} 3 \mathrm{a}$ and $\mathrm{C} 5 \mathrm{a}$ and release of IL-1 and IL-8 [40]. The synthetic peptide formyl-L-methionyl-L-phenylalanine, a potent chemoattractant for human PMN does not induce chemotaxis of bovine PMN [170]. Anti-bovine PMN MAB have been developed that up-regulate chemotaxis of PMN [150]. The mechanisms contributing to this up-regulation have not been elucidated but could be the result of cell activation and expression of either cell surface chemotactic receptors or adhesion molecules.

Differential induction of complement fragment C5a occurs during intramammary infection with E. coli and Staphylococcus aureus [147]. Low levels of C5a are found in milk from $S$. aureus infected cows compared to high levels in milk from cows infected with $E$. coli. This could account for the intense PMN response in milk for cows infected with $E$. coli compared to the attenuated PMN response in cows infected by $S$. aureus, and may contribute to establishment of chronic $S$. aureus mastitis.

\subsection{Cluster of differentiation 14 (CD14)}

Membrane CD14 (mCD14) has been identified on bovine PMN, monocytes and macrophages [136]. LPS binding protein (LBP) binds LPS with high affinity, and the resulting LPS-LBP complex is recognized by $\mathrm{mCD} 14$ and causes activation of those phagocytes (Fig. 4) [188]. The mCD14 is anchored to the membrane surface by a glycosylated phosphatidylinositol (GPI)anchored transmembrane linkage, is easily cleaved off by proteinases in body fluids and results in the formation of soluble CD14 (sCD14) [64]. Soluble CD14 is present in bovine blood and milk [180]. Soluble CD14 binds LPS with high affinity and this complex interacts with Toll-like receptors on epithelial and endothelial cells causing secretion of chemoattractants [188]. Intramammary injection of recombinant bovine sCD14 together with low concentrations of LPS $(0.2 \mu \mathrm{g})$ into lactating dairy cows caused recruitment of PMN when compared to either LPS or CD14 [180]. Intramammary injection of a high concentration of LPS $(100 \mu \mathrm{g})$ causes an increase of sCD14 in milk attributed to 
shedding of mCD14 from recruited PMN, and plays a role in modulating the inflammatory response during coliform mastitis [137]. In addition to its role in modulating the host innate immune response, CD14 has been implicated in mediating resolution of mammary gland injury. Sladek et al., have reported that LPS challenge increases the proportion of CD14+ neutrophils present in mammary glands and that this increase accompanies resolution of the LPS-induced injury [159].

\subsection{Opsonin receptors}

The first event to occur in the process of phagocytosis is contact and recognition. Bacteria resist recognition and recognition or opsonization must be conferred to bacteria before phagocytosis can occur [121]. Immunologic recognition is principally accomplished by specific antibodies that recognize bacterium through $\mathrm{Fab}$ regions and bind to $\mathrm{PMN}$ via Fc-receptors $(\mathrm{FcR})$ on the plasma membrane (Fig. 4). The main opsonizing antibodies for bovine PMN are IgM and $\operatorname{IgG}_{2}[7,111]$. Correlation analysis indicated that $\operatorname{IgM}$ is more highly correlated to phagocytosis than other immunoglobulin isotypes [111]. Contrary to human PMN, bovine PMN do not express Fc $\gamma \mathrm{RI}$ and $\mathrm{Fc} \gamma \mathrm{RII}$ receptors, and have a special receptor for $\mathrm{IgG}_{2}$, the $\mathrm{Fc} \gamma_{2}$ receptor, which is distinct from all other Fc $\gamma$ receptors [192]. Incubation of bovine PMN with recombinant bovine (rbo) interferon- $\gamma$ increases binding of $\mathrm{IgG}_{2}$ and is associated with enhanced PMN function [186]. The increase in PMN function is inhibited by actinomycin $\mathrm{D}$ and puromycin, inhibitors of mRNA transcription and protein translation. Rbointerferon- $\gamma$ does not increase binding of IgM [186]. During in vitro and in vivo chemotaxis of bovine PMN receptors for $\mathrm{IgG}_{2}$ and IgM are expressed [20, 187]. On the other hand, IV endotoxin challenge exposure transiently decreases binding of IgG to PMN [85]. Taken together, these studies indicate that FcR numbers on bovine PMN are under the dynamic control of external factors that are crucial for host defense of the mammary gland.

The $\mathrm{C} 3 \mathrm{~b}$ component of complement also opsonizes bacteria and binds to CR1 receptors on PMN [10, 60, 78]. Bovine $\mathrm{C} 3 \mathrm{~b}$ has been purified and used to study its binding to CR1 on bovine PMN [43]. The CR1 receptor is more abundant on mammary PMN compared to blood PMN indicating that migration of PMN from blood into milk induces expression of CR1, similar to that observed for $\operatorname{IgM}$ and $\operatorname{IgG}_{2}$. However, mammary PMN have diminished up regulation of $\mathrm{CR} 1$ in the presence of inflammatory activators compared to blood PMN suggesting that the intracellular pool of CR1 was expended as a consequence of chemotaxis.

An important phagocytic mechanism for control of intramammary infection by Gram-negative bacteria is non-opsonic phagocytosis [45, 136]. Non-immunological recognition consists of lectins and hydrophobic properties of cell surfaces (Fig. 5). Carbohydrate receptors on the cell surface of bovine PMN mediate interaction with carbohydrate-rich pili of Gramnegative bacteria. This lectin-carbohydrate interaction results in recognition and phagocytosis of Gram-negative bacteria in the absence of specific opsonins. In a recent in vitro study, $80 \%$ of the PMN were able to adhere E. coli and $18 \%$ were able to phagocytose $E$. coli in the absence of opsonins [136]. Such an event, in the absence of significant phagocytosis, would allow a flushing out of E. coli adhered to PMN during milking.

\subsection{Adhesion receptors}

The adhesion molecules CR3 and L-selectin (CD62L) are present on bovine PMN [43, 179]. Both L-selectin and $\beta_{2}$-integrins contain $\mathrm{Ca}^{2+}$-binding domains, and their binding to ligands is $\mathrm{Ca}^{2+}$ dependent [87]. Complement receptor CR3 (Mac-1, $\mathrm{CD} 11 \mathrm{~b} / \mathrm{CD} 18$ ) is a member of a family of leukocyte adhesion molecules also referred 


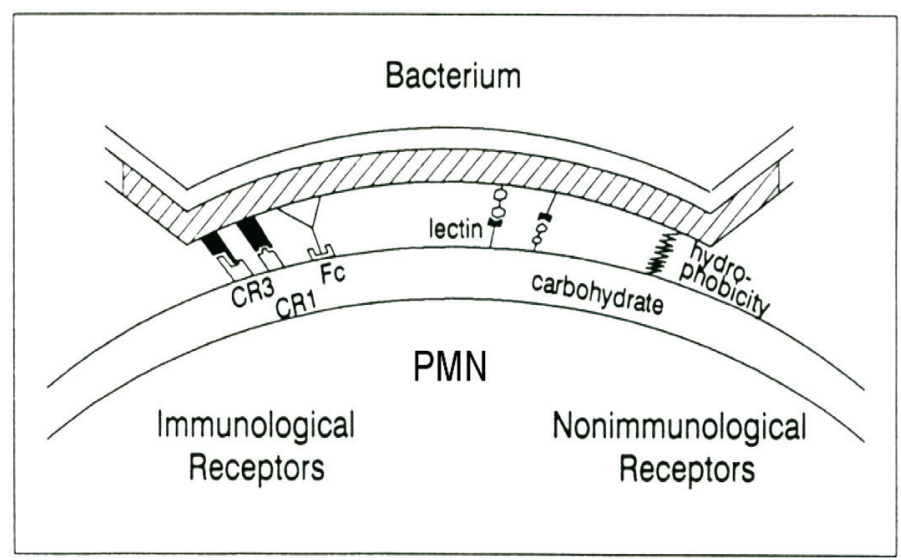

Figure 5. Immunological recognition of bacteria is conferred by $\mathrm{Fc}$ and complement receptors on the surface of polymorphonuclear neutrophil leukocytes, and non-immunological recognition is conferred by lectin, carbohydrate and hydrophobic interactions (adapted from [121]).

to as $\beta_{2}$ integrins, consisting of three noncovalently linked heterodimers LFA-1 (CD11a/CD18), MAC-1 (CD11b/CD18) and p150.95 (CD11c/CD18). These molecules bind to endothelial intercellular adhesion molecules (ICAM-1 and ICAM-2), C3bi and endothelial leukocyte adhesion molecules (ELAM-1) on the endothelial surface $[1,3]$. The dominant $\beta_{2}$ integrin expressed on bovine PMN is CD $11 \mathrm{~b} / \mathrm{CD} 18$ with a $185 \mathrm{kDa} \alpha$ chain and a $95 \mathrm{kDa}$ $\beta$ chain $[90,98]$.

Diapedesis of bovine PMN was studied using monolayers of primary mammary endothelium, collagen matrices and monolayers of primary mammary epithelium. Migration of PMN across endothelial cells is almost completely dependent on CD18, the $\beta$-chain of $\beta_{2}$ integrins, and to a lesser extent on CD11b, one of the $\alpha$-chains of the $\beta_{2}$ integrins, because PMN migration is partially blocked by MAB to CD18 [162, 164]. No inhibition is observed by MAB to CD11b. However, diapedesis of PMN across mammary epithelial cells was blocked by MAB to CD11b. Those results provide evidence for different CD11b/ CD18 dependent mechanisms for PMN diapedesis across various cell layers of the blood-milk barrier. A genetic deficiency of CD11/CD18 called bovine leukocyte adhesion deficiency (BLAD) has been associated with an autosomal recessive granulocytopathy syndrome in cattle [90]. PMN of BLAD animals have defective chemotactic and phagocytic activity but higher oxidative burst activity than normal animals [117, 118].

The L-selectin protein is constitutively expressed on PMN surfaces. It mediates rolling of PMN along the endothelium lining postcapillary venules and localizes PMN to endothelium adjacent to inflamed tissue. L-selectin molecules are attached to the PMN membrane by a GPI-linkage [64]. Expression of L-selectin on the surface of bovine PMN is influenced by cytokines, steroids and physiological and pathological events. The cytokines C5a and IL-8, released during intramammary infection, trigger proteolytic shedding of L-selectin on bovine PMN and simultaneously increase expression of CD18 [87, 107]. CD18 mediates firm attachment of PMN to endothelium and helps PMN move across the vascular endothelium. Activation of human PMN with PMA, leukotriene B4, IL-1, LPS and granulocyte-macrophage 
colony stimulating factor (GM-CSF) induces shedding of L-selectin [87]. Importantly, the inflammatory mediators PAF and TNF induce an increase in size of bovine PMN and may slow diapedesis of PMN through the microvasculature of the mammary gland [108]. Treatment of cows with dexamethasone and cortisol results in down-regulation of membrane bound L-selectin on resting and activated PMN and increases mammary gland susceptibility to $S$. aureus following experimental challenge [25]. Following experimental infection of the mammary gland with E. coli, a decrease in L-selectin expression is observed on circulating PMN [112]. Such an event may be important in controlling over migration of PMN into milk. The increased concentration of plasma glucocorticoids that occurs after experimental challenge of the mammary gland with $E$. coli endotoxin contributes to the decrease in L-selectin expression [126]. A reduced expression of L-selectin on bovine PMN around parturition has been reported [98, 113]. This reduction in L-selectin may have a negative impact on the ability of PMN to be recruited into the mammary gland, and could contribute to the increase in intramammary infection around parturition $[28,106]$. L-selectin mRNA expression as a consequence of elevated plasma glucocorticoids is correlated to reduced surface expression of L-selectin on bovine PMN [184]. This indicates that bovine PMN have the capacity to alter L-selectin gene expression in response to changes in plasma glucocorticoids. Studies performed on human endothelial cells demonstrated that $17 \beta$-estradiol, which is also elevated at parturition, inhibits IL-1 mediated endothelial cell adhesion molecule transcription, and results in diminished membrane protein expression and reduced IL-1 induced leukocyte adhesion [32].

Monoclonal antibodies (MAB 11G10 and 2G8) were produced against bovine L-selectin and have been used to study modulation of these adhesion molecules on bovine PMN [150, 179]. Pretreatment of bovine PMN with anti-bovine L-selectin MAB $11 \mathrm{G} 10$ and $2 \mathrm{G} 8$ reduces chemotaxis and increases native chemiluminescence activity. Crosslinking both MAB with second antibody induces a rapid increase in intracellular free calcium concentration.

\section{FUNCTIONAL ACTIVITY OF BOVINE BLOOD AND MAMMARY PMN}

\subsection{Bactericidal and respiratory burst activity}

Once complement components and immunoglobulins bind to receptors on the PMN surface, the cell becomes activated and generation of the oxidative burst is initiated (Fig. 6). This response is followed by increased oxygen consumption and hexose monophosphate activity and is called the "respiratory burst" [88]. Stimulation of NADPH oxidase in the plasma membrane initiates hexose monophosphate activity. Bovine PMN release large amounts of superoxide $\left(\mathrm{O}_{2}^{-}\right)$and hydrogen peroxide $\left(\mathrm{H}_{2} \mathrm{O}_{2}\right)$ when their plasma membrane is perturbed $[46,100,109,183]$. The $\mathrm{O}_{2}{ }^{-}$and $\mathrm{H}_{2} \mathrm{O}_{2}$ formed on the cell surface and phagosomal membrane interact to form hydroxyl radical and singlet oxygen, key components of oxygen-dependent killing mechanisms of PMN. When the phagosome containing ingested microorganisms fuses with primary or azurophil granules of PMN, myeloperoxidase is released. This enzyme catalyzes formation of hypochlorite, an oxidizing agent from $\mathrm{Cl}^{-}$and $\mathrm{H}_{2} \mathrm{O}_{2}$. The respiratory burst can be monitored by measuring chemiluminescence (CL) activity of PMN. Highly unstable oxygen metabolites are in electronically excited states, and excitation is accompanied by emission of light or CL. Chemiluminescence is enhanced by use of the substrates luminol or lucigenin [5]. Stimulatory effects of various immunoglobulin and zymosan preparations that react with either $\mathrm{Fc}$ or complement receptors or with both 


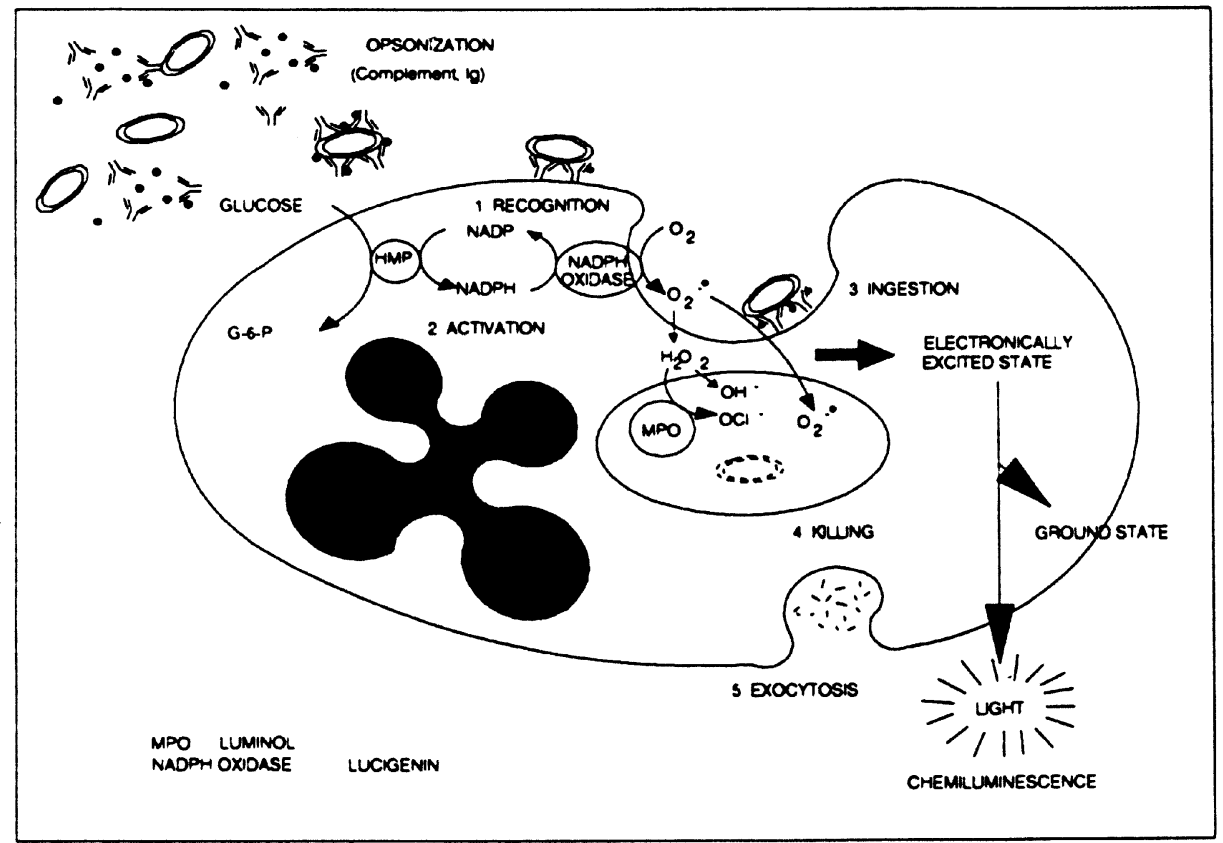

Figure 6. Once complement and immunoglobulins bind to receptors on the surface of polymorphonuclear neutrophil leukocytes, the cell becomes activated and generation of the oxidative burst is initiated.

on luminol-dependent $\mathrm{CL}$ responses of isolated bovine PMN have been described $[100,101]$. Unopsonized zymosan in the presence of extracellular divalent cations binds to C3bi receptors of bovine PMN and induce a strong CL response. Zymosan opsonized with bovine $\mathrm{IgG}_{1}, \mathrm{IgG}_{2}$, fresh serum or serum from which zymosan-specific antibodies but not complement have been removed also induces strong CL responses, with nearly equal maximal peaks. Zymosan opsonized in fetal bovine serum produces a markedly lower CL response. PMN from BLAD calves fail to produce a CL response with C3-opsonized zymosan but produce a CL response to $\mathrm{IgG}_{2}$ opsonized zymosan [100].

A panel of MAB to bovine PMN surface antigens were produced that stimulated CL 2.5 fold when reacted with isolated blood
PMN [150]. To determine if these MAB may provide a novel means of enhancing PMN function three bispecific antibodies (BsAb) were produced [173]. These BsAb were formed by chemically coupling antibovine PMN MAB and anti-S. aureus capsular polysaccharide $5(\mathrm{Cp} 5) \mathrm{MAB}$ with the crosslinking compound $\mathrm{N}$-succinimidyl-3(2-pyridithiol)-propionate. BsAb increased intracellular killing of $S$. aureus by PMN 2 to 3 fold [173]. These data suggest that BsAb immunotherapy may serve as an alternative to antibiotic treatment against bovine mastitis, and may be used to target and kill antibiotic-resistant pathogens that infect the mammary gland.

Native CL activity of unstimulated PMN isolated from milk is higher compared to unstimulated PMN isolated from blood [46, 109]. The higher CL response of milk PMN 
was attributed to a triggering of the CL response through ingestion of milk fat globules and casein micelles with subsequent degranulation. Stimulation of milk cells with PMA results in a decreased capacity to produce reactive oxygen species (ROS) when compared to blood PMN [109]. This indicates that milk PMN are less responsive to stimulating agents because they have been stimulated by milk components. This pre-stimulated status will progressively lead to a functionally exhausted cell.

Diapedesis of PMN across mammary epithelium in vitro reduces ROS production of PMN, and also contributes to reduced bactericidal activity of milk PMN [163]. Adherence of bovine PMN to extracellular matrix (ECM) proteins (collagen IV, laminin, fibronectin and thrombospondin) reduce ROS production after exposure to inflammatory mediators PAF, TNF and IL-8, whereas adherence to heparan sulfate proteoglycan enhances ROS production [22]. In a field study involving 70 lactating dairy cows, depressed milk PMN CL activity was associated with intramammary infection by $S$. aureus [139], and suggest a relationship between PMN CL and susceptibility to intramammary infection by $S$. aureus. Such a relationship suggests that intramammary infection may be controlled through enhancement of PMN CL activity.

Variation exists among cows in oxidative burst activity of PMN [149]. Such variation contributes to variation among cows in susceptibility to intramammary infection. Age dependent changes in CL and bactericidal activity of bovine PMN has been documented $[67,110]$. The ability of PMN to phagocytose IgG-coated yeast and CL activity is lower in neonatal calves ( $<1$ week of age) and young calves ( 2 to 4 weeks of age) than in cows ( 2 to 3 years of age). The depression of these PMN functions is attributed to reduced Fc receptors found on PMN isolated from neonatal and young calves, and contributes to the highly susceptible nature of calves to bacterial and viral pathogens [24, 148].
A number of cytokines enhance oxidative burst activity of bovine PMN. These include rboGM-CSF, TNF- $\alpha$ and rbointerferon- $\gamma[68,91,166]$. Although PMN function is related to the outcome of intramammary infection, therapeutic use of cytokines during clinical mastitis to enhance function has not been very promising because of detrimental side effects. On the other hand, rbosomatotrophin (BST) which also increases oxidative burst activity is used to reduce clinical symptoms of mastitis in dairy cows [28, 74]. Cows receiving BST in order to improve milk yield have fewer days of lost milk production due to clinical mastitis than cows not receiving BST [86].

Oxidative burst activity of bovine PMN is influenced by therapeutic agents at concentrations observed after intramammary treatment. Enrofloxacin increases CL activity whereas neomycin, lincomycin, dihydrostreptomycin oxytetracycline, danofloxacin, penicillin, ceftiofur, spiramycin, erythromycin and chloramphenicol reduce oxidative burst activity of bovine PMN [70-72, 134]. Because functional activity of bovine milk PMN is already impaired as a result of ingestion of milk components, use of antibiotics that will not cause further impairment of PMN function becomes more critical in the ability to clear invading bacteria from the mammary gland. Glucococorticosteroids show no adverse effect on oxidative burst activity of bovine PMN at therapeutic concentrations [73].

Slime producing strains of $S$. aureus are more resistant to phagocytosis and intracellular killing by bovine PMN compared to non-slime producing strains [18]. The slime layer prevents binding of immunoglobulins to Fab sites on the cell membrane of $S$. aureus and enhances virulence of the organism by reducing phagocytosis and killing by PMN.

Vitamin E and selenium are critical antioxidants. Cattle consuming feed low in vitamin $\mathrm{E}$ and selenium have increased 
intramammary infections. In vitro and in vivo studies show that vitamin $\mathrm{E}$ and selenium increase function of bovine PMN [65].

\subsection{Phagocytosis}

Milk PMN are less effective phagocytes than blood PMN. This inefficiency is attributed in part to lower energy reserves in the form of stored glycogen, because milk PMN contain $38 \%$ less glycogen than blood PMN [119]. Addition of glucose increases in vitro phagocytosis of milk PMN. For maximal phagocytosis, PMN require a large quantity of plasma membrane for formation of pseudopodia necessary for trapping and engulfing bacteria (Fig. 7). Milk fat globules and casein reduce phagocytosis [124, 128]. This is attributed to internalization of plasma membrane that is used to form phagosomes containing fat and casein. Intracellular killing of phagocytosed bacteria is inhibited by milk components because of loss of lysosomes that fuse with phagosomes containing fat and casein instead of phagosomes containing bacteria [124].
Recombinant bovine interferon- $\gamma, \mathrm{TNF}-\alpha$ and $\mathrm{C} 5 \mathrm{a}^{\text {desArg }}$ and rboGM-CSF upregulate phagocytosis of bovine PMN [68, 91, 141, 143, 166]. Highest phagocytic activity is obtained when TNF- $\alpha$ and C5a ${ }^{\text {desArg }}$ are used together. At the infection site, generation of C5a for recruitment of PMN will synergize with TNF- $\alpha$ secreted by macrophages to increase phagocytosis [137].

A 3-fold difference exists among cows in ability of milk to support phagocytosis and a 2-fold difference in ability of PMN to phagocytose [125, 132]. There is also a negative correlation between presence of clinical mastitis and ability of milk to support phagocytosis. Variation among cows in phagocytosis and intracellular killing might explain differences in susceptibility of the mammary gland to infection. However, the degree to which results from in vitro phagocytosis assays correspond to actual in vivo processes has yet to be determined.

Activation of complement components $\mathrm{C} 3 \mathrm{~b}$ and $\mathrm{C} 3 \mathrm{bi}$, on the surface of bacteria following antibody union promotes phagocytosis by binding to CR1 and CR3 receptors, respectively, on the PMN [118].

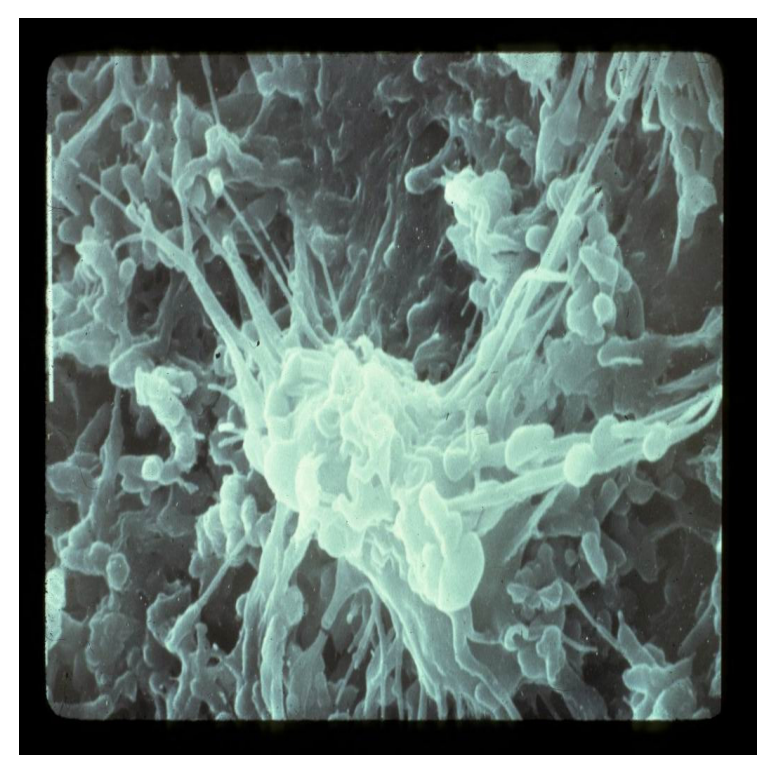

Figure 7. Scanning electron micrograph of a bovine blood polymorphonuclear neutrophil leukocyte with extended pseudopodia phagocytosing Staphylococcus aureus. Numerous individual bacteria can be seen in the process of being phagocytosed, $\times 10000$. 
Fc-mediated phagocytosis of PMN from a heifer lacking cell surface CR3 receptors (BLAD) was $10 \%$ of those of PMN from a normal animal [117]. This suggests that $\mathrm{Fc}$ receptor-mediated phagocytosis is dependent on the presence of CR3 on the PMN surface. This confirmed results from previous studies where PMN from calves homozygous for BLAD had reduced PMN phagocytosis and bactericidal activity than PMN from calves heterozygous for BLAD [156].

A number of pharmacological agents used in dairy cows for the treatment of mastitis and other diseases affect phagocytosis of bovine PMN. Glucocorticoids (corticosteroid anti-inflammatory agents) and adrenocorticotrophic hormone (ACTH), are used in the treatment of some forms of clinical mastitis. However, ACTH at a pharmacological concentration of $200 \mathrm{IU}$ and at a physiological concentration of 100 IU reduces phagocytosis of $S$. aureus by bovine PMN isolated from milk [129, 131]. The $100 \mathrm{IU}$ dose of ACTH produces a plasma glucocorticoid response similar to that observed during acute coliform mastitis [129]. These data indicate that: (1) therapeutic use of ACTH may compromise PMN function, and (2) the glucocorticoid response observed during acute coliform mastitis is sufficient to reduce phagocytosis of PMN, and contributes to reduced clearance of bacteria from the mammary gland. Studies have been conducted that examined the effect of antibiotics, nonsteroidal anti-inflammatory drugs (NSAID) and secretolytic agents within the same chemical class on phagocytic activity of bovine PMN [120, 134, 135]. Concentrations of drugs used approximated concentration in milk following intramammary use. The potential for enhanced phagocytosis exists through use of some NSAID and for depressed phagocytosis through use of aminoglycosides, chloramphenicol, peptolids, tetracyclines and $\beta$-lactams as well as certain nonsteroidal and anti-inflammatories. As more research becomes available, choice of an antibiotic should depend not only on the sensitivity of the organism to the drug, but also to the effect of the drug on host defense mechanisms.

\subsection{Chemotaxis}

In response to chemotactic stimuli generated by invading pathogens, PMN migrate (diapedesis) from blood through the endothelium, subepithelial matrix, basement membrane and mammary epithelium into milk. Migration of PMN is aided by release of matrix metalloproteinases through degranulation during transendothelial and transepithelial migration and breaks down ECM (basement membrane and tissue stroma) [104]. These proteinases degrade collagen, laminin, fibronectins, elastin and the protein core of proteoglycans [104, 144]. However, diapedesis utilizes energy reserves of PMN needed for efficient phagocytosis and killing of invading pathogens [119]. Consequently, diapedesis of PMN across mammary epithelium results in decreased phagocytosis and oxidative burst activity [154]. Upon entering the mammary gland, PMN ingest fat and casein, which further decrease phagocytosis of invading pathogens [124, 128]. As a result, large numbers of PMN are needed to prevent infection of the mammary gland. This led researchers to develop ways of inducing milk PMN neutrophilia to prevent establishment of intramammary infection. The protection offered by PMN against establishment of intramammary infection is greatest when PMN are present at concentrations over $500000 / \mathrm{mL}$ of milk [84, 155]. Resident mammary PMN initiate events that lead to increased vascular permeability and infiltration of blood PMN into the mammary gland [154]. Thus, high concentrations of PMN in the teat cistern would not only be effective as a phagocytic barrier, but would initiate a more rapid infiltration of PMN into milk after infection. The high concentration of PMN would reduce the 24 hours delay in the appearance of PMN in 
milk after entry of pathogenic organisms into the mammary gland [132].

A polyethylene intramammary device (IMD) was inserted into gland cisterns of cows in order to increase diapedesis of PMN into milk to concentrations that protected cows from intramammary infection [133]. Insertion of the IMD elevates MSCC in stripping milk and reduces intramammary infection after experimental intramammary challenge with $S$. aureus, E. coli and Streptococcus uberus. The AIMD is $100 \%$ effective in preventing infection when the cell count exceed $900000 / \mathrm{mL}$ of stripping milk. Results from field trials report a $75 \%$ decrease in clinical mastitis in cows with AIMD [57, 133]. Bucket MSCC from cows in late lactation with AIMD is more than double $\left(400 \times 10^{3} / \mathrm{mL}\right)$ counts from control cows. The legal limit for bulk tank MSCC in the United States is $750 \times$ $10^{3} / \mathrm{mL}$ and in the European Union the legal limit is $400 \times 10^{3} / \mathrm{mL}$ [123]. Because of concerns that the AIMD would cause MSCC to approach legal limits it was never adopted as a method for controlling mastitis in dairy cows.

Based on the discovery that rbosCD14 in the presence of low concentrations of LPS increase MSCC [180], cooperative studies were conducted between the USDA and McGill University to determine if rbosCD14 would be protective after intramammary challenge with $E$. coli. A more rapid diapedesis of PMN occurred in mammary quarters injected with $E$. coli plus rbosCD14, and caused a rapid clearance of $E$. coli compared to quarters injected with only E. coli. It was previously shown that quick recruitment of PMN into the mammary gland following experimental challenge with $E$. coli was critical for elimination of the organisms and resolution of the infection [106]. Taken as a whole, rapid recruitment of PMN into the mammary gland to concentrations that are protective (> 900 000/mL of milk) appears critical in preventing intramammary infection.

\section{FUTURE DIRECTIONS}

Bovine PMN constitute the first intramammary defense against bacterial invasion. Over the last several decades, a large body of information has accumulated on the unique characteristics of bovine PMN in blood and milk. However, the biochemical pathways involved in bovine PMN activation and functionality have not been completely delineated. The rapidly growing area of molecular biology and bioinformatics will lead to quick resolution of these unsolved pathways.

Rapid recruitment of sufficient numbers of PMN into the mammary gland and increased phagocytosis at the beginning of infection prevent establishment of mastitis. This can be accomplished by inducing increased production of chemoattractants, increased expression of cell surface chemotactic receptors or adhesion molecules and increased opsonization of invading bacteria. This concept has been confirmed using the IMD and intramammary injection of CD14. In addition to its effect on migration of PMN, other roles of CD14 in the inflammatory response need to be clarified before application of CD14 transgenic animals to prevent mastitis.

Knowledge of mechanisms about when and where PMN degranulation and secretion occur would be of extreme value as we attempt to preserve the beneficial, protective aspects of inflammatory cell accumulation while seeking to limit injurious effects to mammary tissue. The content in PMN granules, in particular antimicrobial proteins, needs to be further identified and characterized. Insight into the structure of those naturally occurring antimicrobial agents can be potentially used to design new classes of therapeutics.

PMN function is tightly regulated, in particular by cytokines. A better understanding of the orchestration of the synthesis of cytokines for a more specific inflammatory response such as granulopoiesis, PMN recruitment, phagocytosis 
and degranulation is prerequisite for manipulation of PMN function by use of cytokines.

The life span of PMN is limited by the onset of apoptosis. By delaying the onset of this process, increased numbers of PMN will be available to mount a defense against invading microorganism. Inhibitors of apoptosis that block caspase activation have been successfully used in vivo. Whether these agents can augment the ability of bovine PMN to fight infection by prolonging the onset of PMN apoptosis remains unknown. Once infection is cleared, however, accelerated PMN apoptosis is desirable in order to prevent PMN-mediated injury to the epithelial lining of the mammary gland. Caspase inhibitors block inflammatory mediator-induced apoptosis in both sepsis and endotoxin shock models. The efficacy of these agents in limiting epithelial injury during mastitis warrants future consideration.

\section{REFERENCES}

[1] Ackermann M.R., Kehrli M.E. Jr, Brogden K.A., Passage of CD18- and CD18+ bovine neutrophils into pulmonary alveoli during acute Pasteurella haemolytica pneumonia, Vet. Pathol. 33 (1996) 639-646.

[2] Adams J.M., Cory S., The Bcl-2 protein family: arbiters of cell survival, Science 281 (1998) 1322-1326.

[3] Agace W.W., Patarroyo M., Svensson M., Carlemalm E., Svanborg C., Escherichia coli induces transuroepithelial neutrophil migration by an intercellular adhesion molecule-1dependent mechanism, Infect. Immun. 63 (1995) 4054-4062.

[4] Akgul C., Moulding D.A., Edwards S.W., Molecular control of neutrophil apoptosis, FEBS Lett. 487 (2001) 318-322.

[5] Allen R.C., Loose L.D., Phagocytic activation of a luminol-dependent chemiluminescence in rabbit alveolar and peritoneal macrophages, Biochem. Biophys. Res. Commun. 69 (1976) 245-252.

[6] Allgaier B., Shi M., Luo D., Koenig J.M., Spontaneous and Fas-mediated apoptosis are diminished in umbilical cord blood neutrophils compared with adult neutrophils, J. Leukoc. Biol. 64 (1998) 331-336.
[7] Anderson K.L., Smith A.R., Shanks R.D., Whitmore H.L., Davis L.E., Gustafsson B.K., Endotoxin-induced bovine mastitis: immunoglobulins, phagocytosis, and effect of flunixin meglumine, Am. J. Vet. Res. 47 (1986) 2405-2410.

[8] Antonsson B., Martinou J.C., The Bcl-2 protein family, Exp. Cell Res. 256 (2000) 50-57.

[9] Arditi M., Zhou J., Dorio R., Rong G.W., Goyert S.M., Kim K.S., Endotoxin-mediated endothelial cell injury and activation: role of soluble CD14, Infect. Immun. 61 (1993) 3149-3156.

[10] Arnaout M.A., Melamed J., Tack B.F., Colten H.R., Characterization of the human complement $(\mathrm{c} 3 \mathrm{~b})$ receptor with a fluid phase C3b dimer, J. Immunol. 127 (1981) 13481354.

[11] Ashkenazi A., Dixit V.M., Death receptors: signaling and modulation, Science 281 (1998) 1305-1308.

[12] Baggiolini M., Horisberger U., Gennaro R., Dewald B., Identification of three types of granules in neutrophils of ruminants. Ultrastructure of circulating and maturing cells, Lab. Invest. 52 (1985) 151-158.

[13] Bainton D.F., Sequential degranulation of the two types of polymorphonuclear leukocyte granules during phagocytosis of microorganisms, J. Cell Biol. 58 (1973) 249-264.

[14] Bainton D.F., Ullyot J.L., Farquhar M.G., The development of neutrophilic polymorphonuclear leukocytes in human bone marrow, J. Exp. Med. 134 (1971) 907-934.

[15] Bannerman D.D., Sathyamoorthy M., Goldblum S.E., Bacterial lipopolysaccharide disrupts endothelial monolayer integrity and survival signaling events through caspase cleavage of adherens junction proteins, J. Biol. Chem. 273 (1998) 35371-35380.

[16] Bannerman D.D., Tupper J.C., Ricketts W.A., Bennett C.F., Winn R.K., Harlan J.M., A constitutive cytoprotective pathway protects endothelial cells from lipopolysaccharide-induced apoptosis, J. Biol. Chem. 276 (2001) 14924-14932.

[17] Barber M.R., Yang T.J., Chemotactic activities in nonmastitic and mastitic mammary secretions: presence of interleukin-8 in mastitic but not nonmastitic secretions, Clin. Diagn. Lab. Immunol. 5 (1998) 82-86.

[18] Barrio B., Vangroenweghe F., Dosogne H., Burvenich C., Decreased neutrophil bactericidal activity during phagocytosis of a slimeproducing Staphylococcus aureus strain, Vet. Res. 31 (2000) 603-609. 
[19] Bazzoni F., Giovedi S., Kiefer M.C., Cassatella M.A., Analysis of the Bak protein expression in human polymorphonuclear neutrophils, Int. J. Clin. Lab. Res. 29 (1999) 41-45.

[20] Berning L.M., Paape M.J., Peters R.R., Alterations in phagocytosis and the binding of immunoglobulin to bovine neutrophils after chemotaxis, Comp. Haematol. Int. 1 (1991) 129-134.

[21] Biffl W.L., Moore E.E., Moore F.A., Barnett C.C. Jr., Interleukin-6 suppression of neutrophil apoptosis is neutrophil concentration dependent, J. Leukoc. Biol. 58 (1995) 582 584.

[22] Borgquist J.D., Quinn M.T., Swain S.D., Adhesion to extracellular matrix proteins modulates bovine neutrophil responses to inflammatory mediators, J. Leukoc. Biol. 71 (2002) 764-774.

[23] Brown S.B., Savill J., Phagocytosis triggers macrophage release of Fas ligand and induces apoptosis of bystander leukocytes, J. Immunol. 162 (1999) 480-485.

[24] Bryson D.G., McFerran J.B., Ball H.J., Neill S.D., Observations on outbreaks of respiratory disease in housed calves--(1) Epidemiological, clinical and microbiological findings, Vet. Rec. 103 (1978) 485-489.

[25] Burton J.L., Kehrli M.E. Jr., Regulation of neutrophil adhesion molecules and shedding of Staphylococcus aureus in milk of cortisoland dexamethasone-treated cows, Am. J. Vet. Res. 56 (1995) 997-1006.

[26] Burton J.L., Kehrli M.E. Jr., Kapil S., Horst R.L., Regulation of L-selectin and CD18 on bovine neutrophils by glucocorticoids: effects of cortisol and dexamethasone, J. Leukoc. Biol. 57 (1995) 317-325.

[27] Burvenich C., Paape M.J., Hill A.W., Guidry A.J., Miller R.H., Heyneman R., Kremer W.D., Brand A., Role of the neutrophil leucocyte in the local and systemic reactions during experimentally induced $E$. coli mastitis in cows immediately after calving, Vet. Q. 16 (1994) 45-50

[28] Burvenich C., Paape M.J., Hoeben D., Dosogne H., Massart-Leen A.M., Blum J., Modulation of the inflammatory reaction and neutrophil defense of the bovine lactating mammary gland by growth hormone, Domest. Anim. Endocrinol. 17 (1999) 149159.

[29] Capuco A.V., Paape M.J., Nickerson S.C., In vitro study of polymorphonuclear leukocyte damage to mammary tissues of lactating cows, Am. J. Vet. Res. 47 (1986) 663-668.
[30] Carlson G.P., Kaneko J.J., Intravascular granulocyte kinetics in developing calves, Am. J. Vet. Res. 36 (1975) 421-425.

[31] Caswell J.L., Middleton D.M., Gordon J.R., The importance of interleukin-8 as a neutrophil chemoattractant in the lungs of cattle with pneumonic pasteurellosis, Can. J. Vet. Res. 65 (2001) 229-232.

[32] Caulin-Glaser T., Watson C.A., Pardi R., Bender J.R., Effects of 17beta-estradiol on cytokine-induced endothelial cell adhesion molecule expression, J. Clin. Invest. 98 (1996) 36-42.

[33] Chen J.J., Sun Y., Nabel G.J., Regulation of the proinflammatory effects of Fas ligand (CD95L), Science 282 (1998) 1714-1717.

[34] Chin A.C., Morck D.W., Merrill J.K., Ceri H., Olson M.E., Read R.R., Dick P., Buret A.G., Anti-inflammatory benefits of tilmicosin in calves with Pasteurella haemolyticainfected lungs, Am. J. Vet. Res. 59 (1998) $765-771$.

[35] Chin A.C., Lee W.D., Murrin K.A., Morck D.W., Merrill J.K., Dick P., Buret A.G., Tilmicosin induces apoptosis in bovine peripheral neutrophils in the presence or in the absence of Pasteurella haemolytica and promotes neutrophil phagocytosis by macrophages, Antimicrob. Agents Chemother. 44 (2000) 2465-2470.

[36] Chuang P.I., Yee E., Karsan A., Winn R.K., Harlan J.M., A1 is a constitutive and inducible $\mathrm{Bcl}-2$ homologue in mature human neutrophils, Biochem. Biophys. Res. Commun. 249 (1998) 361-365.

[37] Colotta F., Re F., Polentarutti N., Sozzani S., Mantovani A., Modulation of granulocyte survival and programmed cell death by cytokines and bacterial products, Blood 80 (1992) 2012-2020.

[38] Cox G., Crossley J., Xing Z., Macrophage engulfment of apoptotic neutrophils contributes to the resolution of acute pulmonary inflammation in vivo, Am. J. Respir. Cell Mol. Biol. 12 (1995) 232-237.

[39] Coxon A., Rieu P., Barkalow F.J., Askari S., Sharpe A.H., von Andrian U.H., Arnaout M.A., Mayadas T.N., A novel role for the beta 2 integrin CD11b/CD18 in neutrophil apoptosis: a homeostatic mechanism in inflammation, Immunity 5 (1996) 653-666.

[40] Craven N., Chemotactic factors for bovine neutrophils in relation to mastitis, Comp. Immunol. Microbiol. Infect. Dis. 9 (1986) 29-36. 
[41] Daigle I., Simon H.U., Critical role for caspases 3 and 8 in neutrophil but not eosinophil apoptosis, Int. Arch. Allergy Immunol. 126 (2001) 147-156.

[42] Daley M.J., Coyle P.A., Williams T.J., Furda G., Dougherty R., Hayes P.W., Staphylococcus aureus mastitis: pathogenesis and treatment with bovine interleukin-1 beta and interleukin-2, J. Dairy Sci. 74 (1991) 4413 4424.

[43] Di Carlo A.L., Paape M.J., Miller R.H., Reactivity of purified complement component $3 \mathrm{~b}$ with bovine neutrophils and modulation of complement receptor 1, Am. J. Vet. Res. 57 (1996) 151-156.

[44] Dibbert B., Weber M., Nikolaizik W.H., Vogt P., Schoni M.H., Blaser K., Simon H.U., Cytokine-mediated Bax deficiency and consequent delayed neutrophil apoptosis: a general mechanism to accumulate effector cells in inflammation, Proc. Natl. Acad. Sci. USA 96 (1999) 13330-13335.

[45] Dosogne H., Burvenich C., Paape M.J., Effect of extracellular ionic calcium and magnesium on opsonic and non-opsonic phagocytes of Escherichia coli bovine blood polymorphonuclear leucocytes, Comp. Haematol. Int. 8 (1998) 82-86.

[46] Dulin A.M., Paape M.J., Nickerson S.C., Comparison of phagocytosis and chemiluminescence by blood and mammary gland neutrophils from multiparous and nulliparous cows, Am. J. Vet. Res. 49 (1988) 172-177.

[47] Epling-Burnette P.K., Zhong B., Bai F., Jiang K., Bailey R.D., Garcia R., Jove R., Djeu J.Y., Loughran T.P. Jr., Wei S., Cooperative regulation of Mcl-1 by Janus kinase/stat and phosphatidylinositol 3-kinase contribute to granulocyte-macrophage colony-stimulating factor-delayed apoptosis in human neutrophils, J. Immunol. 166 (2001) 7486-7495.

[48] Fadeel B., Ahlin A., Henter J.I., Orrenius S., Hampton M.B., Involvement of caspases in neutrophil apoptosis: regulation by reactive oxygen species, Blood 92 (1998) 4808-4818.

[49] Fecho K., Cohen P.L., Fas ligand (gld)- and Fas (lpr)-deficient mice do not show alterations in the extravasation or apoptosis of inflammatory neutrophils, J. Leukoc. Biol. 64 (1998) 373-383.

[50] Frank R.W., Gennaro R., Schneider K., Przybylski M., Romeo D., Amino acid sequences of two proline-rich bactenecins. Antimicrobial peptides of bovine neutrophils, J. Biol. Chem. 265 (1990) 18871-18874.
[51] Frasch S.C., Nick J.A., Fadok V.A., Bratton D.L., Worthen G.S., Henson P.M., p38 mitogen-activated protein kinase-dependent and -independent intracellular signal transduction pathways leading to apoptosis in human neutrophils, J. Biol. Chem. 273 (1998) 8389-8397.

[52] Galligan C.L., Coomber B.L., Effects of human IL-8 isoforms on bovine neutrophil function in vitro, Vet. Immunol. Immunopathol. 74 (2000) 71-85.

[53] Gennaro R., Dolzani L., Romeo D., Potency of bactericidal proteins purified from the large granules of bovine neutrophils, Infect. Immun. 40 (1983) 684-690.

[54] Gennaro R., Dewald B., Horisberger U., Gubler H.U., Baggiolini M., A novel type of cytoplasmic granule in bovine neutrophils, $\mathrm{J}$. Cell Biol. 96 (1983) 1651-1661.

[55] Ginis I., Faller D.V., Protection from apoptosis in human neutrophils is determined by the surface of adhesion, Am. J. Physiol. 272 (1997) C295-C309.

[56] Girard D., Paquet M.E., Paquin R., Beaulieu A.D., Differential effects of interleukin-15 (IL-15) and IL-2 on human neutrophils: modulation of phagocytosis, cytoskeleton rearrangement, gene expression, and apoptosis by IL-15, Blood 88 (1996) 3176-3184.

[57] Goodger W.J., Farver T., Galland J., Jasper D., Pelletier J., Effects of a high-density intramammary device on mammary glands, production, and reproductive performance in dairy cows, J. Am. Vet. Med. Assoc. 202 (1993) 1966-1974.

[58] Granville D.J., Carthy C.M., Hunt D.W., McManus B.M., Apoptosis: molecular aspects of cell death and disease, Lab. Invest. 78 (1998) 893-913.

[59] Gray G.D., Knight K.A., Nelson R.D., Herron M.J., Chemotactic requirements of bovine leukocytes, Am. J. Vet. Res. 43 (1982) $757-$ 759.

[60] Grewal A.S., Rouse B.T., Babiuk L.A., Characterization of surface receptors on bovine leukocytes, Int. Arch. Allergy. Appl. Immunol. 56 (1978) 289-300.

[61] Hachiya O., Takeda Y., Miyata H., Watanabe H., Yamashita T., Sendo F., Inhibition by bacterial lipopolysaccharide of spontaneous and TNF-alpha-induced human neutrophil apoptosis in vitro, Microbiol. Immunol. 39 (1995) 715-723.

[62] Hamasaki A., Sendo F., Nakayama K., Ishida N., Negishi I., Hatakeyama S., Accelerated neutrophil apoptosis in mice lacking A1-a, 
a subtype of the bcl-2-related A1 gene, J. Exp. Med. 188 (1998) 1985-1992.

[63] Haslett C., Granulocyte apoptosis and its role in the resolution and control of lung inflammation, Am. J. Respir. Crit. Care Med. 160 (1999) S5-S11.

[64] Haziot A., Chen S., Ferrero E., Low M.G., Silber R., Goyert S.M., The monocyte differentiation antigen, CD14, is anchored to the cell membrane by a phosphatidylinositol linkage, J. Immunol. 141 (1988) 547-552.

[65] Hemingway R.G., The influences of dietary selenium and vitamin $\mathrm{E}$ intakes on milk somatic cell counts and mastitis in cows, Vet. Res. Commun. 23 (1999) 481-499.

[66] Heyneman R., Burvenich C., Kinetics and characteristics of bovine neutrophil alkaline phosphatase during acute Escherichia coli mastitis, J. Dairy Sci. 75 (1992) 1826-1834.

[67] Higuchi H., Nagahata H., Hiroki M., Noda H., Relationship between age-dependent changes of bovine neutrophil functions and their intracellular $\mathrm{Ca}^{2+}$ concentrations, J. Vet. Med. Sci. 59 (1997) 271-276.

[68] Hirai T., Oikawa M., Inumaru S., Yokomizo Y., Kusakari N., Mori K., Effects of recombinant bovine granulocyte-macrophage colony-stimulating factor on bovine peripheral blood neutrophil functions in vitro and in vivo, J. Vet. Med. Sci. 61 (1999) 1249-1251.

[69] Hirata H., Takahashi A., Kobayashi S., Yonehara S., Sawai H., Okazaki T., Yamamoto K., Sasada M., Caspases are activated in a branched protease cascade and control distinct downstream processes in Fas-induced apoptosis, J. Exp. Med. 187 (1998) 587-600.

[70] Hoeben D., Burvenich C., Heyneman R., Influence of antimicrobial agents on bactericidal activity of bovine milk polymorphonuclear leukocytes, Vet. Immunol. Immunopathol. 56 (1997) 271-282.

[71] Hoeben D., Dosogne H., Heyneman R., Burvenich C., Effect of antibiotics on the phagocytotic and respiratory burst activity of bovine granulocytes, Eur. J. Pharmacol. 332 (1997) 289-297.

[72] Hoeben D., Burvenich C., Heyneman R., Antibiotics commonly used to treat mastitis and respiratory burst of bovine polymorphonuclear leukocytes, J. Dairy Sci. 81 (1998) 403-410.

[73] Hoeben D., Burvenich C., Massart-Leen A.M., Glucocorticosteroids and in vitro effects on chemiluminescence of isolated bovine blood granulocytes, Eur. J. Pharmacol. 354 (1998) 197-203.
[74] Hoeben D., Burvenich C., Eppard P.J., Byatt J.C., Hard D.L., Effect of bovine somatotropin on neutrophil functions and clinical symptoms during Streptococcus uberis mastitis, J. Dairy Sci. 82 (1999) 1465-1481.

[75] Hoeben D., Burvenich C., Trevisi E., Bertoni G., Hamann J., Bruckmaier R.M., Blum J.W., Role of endotoxin and TNF-alpha in the pathogenesis of experimentally induced coliform mastitis in periparturient cows, J. Dairy Res. 67 (2000) 503-514.

[76] Hotchkiss R.S., Tinsley K.W., Swanson P.E., Chang K.C., Cobb J.P., Buchman T.G., Korsmeyer S.J., Karl I.E., Prevention of lymphocyte cell death in sepsis improves survival in mice, Proc. Natl. Acad. Sci. USA 96 (1999) 14541-14546.

[77] Hotchkiss R.S., Chang K.C., Swanson P.E., Tinsley K.W., Hui J.J., Klender P., Xanthoudakis S., Roy S., Black C., Grimm E., Aspiotis R., Han Y., Nicholson D.W., Karl I.E., Caspase inhibitors improve survival in sepsis: a critical role of the lymphocyte, Nat. Immunol. 1 (2000) 496-501.

[78] Howard C.J., Taylor G., Brownlie J., Surface receptors for immunoglobulin on bovine polymorphonuclear neutrophils and macrophages, Res. Vet. Sci. 29 (1980) 128-130.

[79] Hoyt D.G., Mannix R.J., Rusnak J.M., Pitt B.R., Lazo J.S., Collagen is a survival factor against LPS-induced apoptosis in cultured sheep pulmonary artery endothelial cells, Am. J. Physiol. 269 (1995) L171-L177.

[80] Hsieh S.C., Huang M.H., Tsai C.Y., Tsai Y.Y., Tsai S.T., Sun K.H., Yu H.S., Han S.H., Yu C.L., The expression of genes modulating programmed cell death in normal human polymorphonuclear neutrophils, Biochem. Biophys. Res. Commun. 233 (1997) 700-706.

[81] Ishii Y., Hashimoto K., Nomura A., Sakamoto T., Uchida Y., Ohtsuka M., Hasegawa S., Sagai M., Elimination of neutrophils by apoptosis during the resolution of acute pulmonary inflammation in rats, Lung 176 (1998) 89-98.

[82] Iwai K., Miyawaki T., Takizawa T., Konno A., Ohta K., Yachie A., Seki H., Taniguchi N., Differential expression of bcl-2 and susceptibility to anti-Fas-mediated cell death in peripheral blood lymphocytes, monocytes, and neutrophils, Blood 84 (1994) 1201-1208.

[83] Jain N.C., Schalm's Veterinary Hematology, 4th ed., Lee and Febiger, Philadelphia, PA, 1986, pp. 676-730. 
[84] Jain N.C., Schalm O.W., Carroll E.J., Lasmanis J., Experimental mastitis in leukopenic cows: immunologically induced neutropenia and response to intramammary inoculation of Aerobacter aerogenes, Am. J. Vet. Res. 29 (1968) 2089-2097.

[85] Jain N.C., Paape M.J., Berning L., Salgar S.K., Worku M., Functional competence and monoclonal antibody reactivity of neutrophils from cows injected with Escherichia coli endotoxin, Comp. Haematol. Int. 1 (1991) 10-20.

[86] Judge L.J., Erskine R.J., Bartlett P.C., Recombinant bovine somatotropin and clinical mastitis: incidence, discarded milk following therapy, and culling, J. Dairy Sci. 80 (1997) 3212-3218.

[87] Jutila M.A., Rott L., Berg E.L., Butcher E.C., Function and regulation of the neutrophil MEL-14 antigen in vivo: comparison with LFA-1 and MAC-1, J. Immunol. 143 (1989) 3318-3324.

[88] Karnovsky M.L., Badwey J.A., Respiratory burst during phagocytosis: an overview, Methods Enzymol. 132 (1986) 353-354.

[89] Kehrli M.E. Jr., Nonnecke B.J., Roth J.A., Alterations in bovine neutrophil function during the periparturient period, Am. J. Vet. Res. 50 (1989) 207-214.

[90] Kehrli M.E. Jr., Schmalstieg F.C., Anderson D.C., Van der Maaten M.J., Hughes B.J., Ackermann M.R., Wilhelmsen C.L., Brown G.B., Stevens M.G., Whetstone C.A., Molecular definition of the bovine granulocytopathy syndrome: identification of deficiency of the Mac-1 (CD11b/CD18) glycoprotein, Am. J. Vet. Res. 51 (1990) 18261836.

[91] Kehrli M.E. Jr., Goff J.P., Stevens M.G., Boone T.C., Effects of granulocyte colonystimulating factor administration to periparturient cows on neutrophils and bacterial shedding, J. Dairy Sci. 74 (1991) 2448 2458.

[92] Kettritz R., Gaido M.L., Haller H., Luft F.C., Jennette C.J., Falk R.J., Interleukin-8 delays spontaneous and tumor necrosis factoralpha-mediated apoptosis of human neutrophils, Kidney Int. 53 (1998) 84-91.

[93] Khwaja A., Tatton L., Caspase-mediated proteolysis and activation of protein kinase Cdelta plays a central role in neutrophil apoptosis, Blood 94 (1999) 291-301.

[94] Klebanoff S.J., Biochemistry of the phagocytic process, North-Holland Publishing Company, London, 1970, pp. 89-114.
[95] Klein J.B., Buridi A., Coxon P.Y., Rane M.J., Manning T., Kettritz R., McLeish K.R., Role of extracellular signal-regulated kinase and phosphatidylinositol-3 kinase in chemoattractant and LPS delay of constitutive neutrophil apoptosis, Cell. Signal. 13 (2001) 335-343

[96] Ledbetter T.K., Paape M.J., Douglass L.W., Cytotoxic effects of peroxynitrite, polymorphonuclear neutrophils, free-radical scavengers, inhibitors of myeloperoxidase, and inhibitors of nitric oxide synthase on bovine mammary secretory epithelial cells, Am. J. Vet. Res. 62 (2001) 286-293.

[97] Lee A., Whyte M.K., Haslett C., Inhibition of apoptosis and prolongation of neutrophil functional longevity by inflammatory mediators, J. Leukoc. Biol. 54 (1993) 283-288.

[98] Lee E.K., Kehrli M.E. Jr., Expression of adhesion molecules on neutrophils of periparturient cows and neonatal calves, Am. J. Vet. Res. 59 (1998) 37-43.

[99] Lee J., Zhao X., Recombinant human interleukin-8, but not human interleukin-1beta, induces bovine neutrophil migration in an in vitro co-culture system, Cell Biol. Int. 24 (2000) 889-895.

[100] Leino L., Paape M.J., Comparison of the chemiluminescence responses of bovine neutrophils to differently opsonized zymosan particles, Am. J. Vet. Res. 54 (1993) 1055 1059.

[101] Leino L., Paape M.J., Regulation of activation of bovine neutrophils by aggregated immunoglobulin G, Am. J. Vet. Res. 57 (1996) 1312-1316.

[102] Leuenroth S., Lee C., Grutkoski P., Keeping H., Simms H.H., Interleukin-8-induced suppression of polymorphonuclear leukocyte apoptosis is mediated by suppressing CD95 (Fas/Apo-1) Fas-1 interactions, Surgery 124 (1998) 409-417.

[103] Leuenroth S.J., Grutkoski P.S., Ayala A., Simms H.H., The loss of Mcl-1 expression in human polymorphonuclear leukocytes promotes apoptosis, J. Leukoc. Biol. 68 (2000) 158-166

[104] Li X., Zhao X., Ma S., Secretion of 92 kDa gelatinase (MMP-9) by bovine neutrophils, Vet. Immunol. Immunopathol. 67 (1999) 247-258.

[105] Liles W.C., Kiener P.A., Ledbetter J.A., Aruffo A., Klebanoff S.J., Differential expression of Fas (CD95) and Fas ligand on normal human phagocytes: implications for the regulation of apoptosis in neutrophils, $\mathrm{J}$. Exp. Med. 184 (1996) 429-440. 
[106] Lohuis J.A.C.M., Burvenich C., Pathogenesis of experimentally induced Escherichia coli mastitis in cows, Flem. Vet. J. 66 (1997) 205-215.

[107] McClenahan D., Fagliari J., Evanson O., Weiss D., Role of inflammatory mediators in priming, activation, and deformability of bovine neutrophils, Am. J. Vet. Res. 61 (2000) 492-498.

[108] McClenahan D.J., Evanson O.A., Walcheck B.K., Weiss D.J., Association among filamentous actin content, CD11b expression, and membrane deformability in stimulated and unstimulated bovine neutrophils, Am. J. Vet. Res. 61 (2000) 380-386.

[109] Mehrzad J., Dosogne H., Vangroenweghe F., Burvenich C., A comparative study of bovine blood and milk neutrophil functions with luminol-dependent chemiluminescence, Luminescence 16 (2001) 343-356.

[110] Mehrzad J., Duchateau L., Pyörälä S., Burvenich C., Blood and milk neutrophil chemiluminescence and viability in primiparous and pluriparous dairy cows during late pregnancy, around parturition and early lactation, J. Dairy Sci. 85 (2002) 3268-3276.

[111] Miller R.H., Guidry A.J., Paape M.J., Dulin A.M., Fulton L.A., Relationship between immunoglobulin concentrations in milk and phagocytosis by bovine neutrophils, Am. J. Vet. Res. 49 (1988) 42-45.

[112] Monfardini E., Burvenich C., Massart-Leen A.M., Smits E., Paape M.J., Effect of antibiotic induced bacterial clearance in the udder on L-selectin shedding of blood neutrophils in cows with Escherichia coli mastitis, Vet. Immunol. Immunopathol. 67 (1999) 373384.

[113] Monfardini E., Paape M.J., Wang Y., Capuco A.V., Husheem M., Wood L., Burvenich C., Evaluation of L-selectin expression and assessment of protein tyrosine phosphorylation in bovine polymorphonuclear neutrophil leukocytes around parturition, Vet. Res. 33 (2002) 271-281.

[114] Moulding D.A., Quayle J.A., Hart C.A., Edwards S.W., Mcl-1 expression in human neutrophils: regulation by cytokines and correlation with cell survival, Blood 92 (1998) 2495-2502.

[115] Moulding D.A., Akgul C., Derouet M., White M.R., Edwards S.W., BCL-2 family expression in human neutrophils during delayed and accelerated apoptosis, J. Leukoc. Biol. 70 (2001) 783-792.

[116] Muzio M., Stockwell B.R., Stennicke H.R., Salvesen G.S., Dixit V.M., An induced proximity model for caspase- 8 activation, $\mathrm{J}$ Biol. Chem. 273 (1998) 2926-2930.

[117] Nagahata H., Kehrli M.E. Jr., Murata H., Okada H., Noda H., Kociba G.J., Neutrophil function and pathologic findings in Holstein calves with leukocyte adhesion deficiency, Am. J. Vet. Res. 55 (1994) 40-48.

[118] Nagahata H., Sawada C., Higuchi H., Teraoka H., Yamaguchi M., Fc receptormediated phagocytosis, superoxide production and calcium signaling of beta 2 integrindeficient bovine neutrophils, Microbiol. Immunol. 41 (1997) 747-750.

[119] Newbould F.H., The effect of added serum and glucose, and some inherent factors, on phagocytosis in vitro by milk leukocytes from several cows, Can. J. Comp. Med. 37 (1973) 189-194.

[120] Nickerson S.C., Paape M.J., Dulin A.M., Effect of antibiotics and vehicles on bovine mammary polymorphonuclear leukocyte morphologic features, viability, and phagocytic activity in vitro, Am. J. Vet. Res. 46 (1985) 2259-2265.

[121] Ohman L., Maluszynska G., Magnusson K.E., Stendahl O., Surface interaction between bacteria and phagocytic cells, Prog. Drug Res. 32 (1988) 131-147.

[122] Oseas R., Yang H.H., Baehner R.L., Boxer L.A., Lactoferrin: a promoter of polymorphonuclear leukocyte adhesiveness, Blood 57 (1981) 939-945.

[123] Paape M.J., Contreras A., Historical perspective on the evolution of the milk somatic cell count, Flem. Vet. J. 66 (1997) 93-105.

[124] Paape M.J., Guidry A.J., Effect of fat and casein on intracellular killing of Staphylococcus aureus by milk leukocytes, Proc. Soc. Exp. Biol. Med. 155 (1977) 588-593.

[125] Paape M.J., Wergin W.P., The leukocyte as a defense mechanism, J. Am. Vet. Med. Assoc. 170 (1977) 1214-1223.

[126] Paape M.J., Schultze W.D., Desjardins C., Miller R.H., Plasma corticosteroid, circulating leukocyte and milk somatic cell responses to Escherichia coli endotoxininduced mastitis, Proc. Soc. Exp. Biol. Med. 145 (1974) 553-559.

[127] Paape M.J., Carroll D.W., Kral A.J., Miller R.H., Desjardins C., Corticosteroids, circulating leukocytes, and erythrocytes in cattle: diurnal changes and effects of bacteriologic status, stage of lactation, and milk yield on response to adrenocorticotropin, Am. J. Vet. Res. 35 (1974) 355-362. 
[128] Paape M.J., Guidry A.J., Kirk S.T., Bolt D.J., Measurement of phagocytosis of ${ }^{32} \mathrm{P}$ labeled Staphylococcus aureus by bovine leukocytes: lysostaphin digestion and inhibitory effect of cream, Am. J. Vet. Res. 36 (1975) 1737-1743.

[129] Paape M.J., Desjardins C., Guidry A.J., Miller R.H., Smith V.R., Response of plasma corticosteroids and circulating leukocytes in cattle following intravenous injection of different doses of adrenocorticotropin, Am. J. Vet. Res. 38 (1977) 13451348.

[130] Paape M.J., Pearson R.E., Wergin W.P., Guidry A.J., Enhancement of chemotactic response of polymorphonuclear leukocytes into the mammary gland and isolation from milk, J. Dairy Sci. 60 (1977) 53-62.

[131] Paape M.J., Wergin W.P., Guidry A.J., Pearson R.E., Leukocytes--second line of defense against invading mastitis pathogens, J. Dairy Sci. 62 (1979) 135-153.

[132] Paape M.J., Wergin W.P., Guidry A.J., Schultze W.D., Phagocytic defense of the ruminant mammary gland, Adv. Exp. Med. Biol. 137 (1981) 555-578.

[133] Paape M.J., Ziv G., Miller R.H., Schultze W.D., Update on the use of intrammamary devices in the control of mastitis, 25th Annual National Mastitis Council Meetings (1986) 87-103.

[134] Paape M.J., Miller R.H., Ziv G., Effects of florfenicol, chloramphenicol, and thiamphenicol on phagocytosis, chemiluminescence, and morphology of bovine polymorphonuclear neutrophil leukocytes, J. Dairy Sci. 73 (1990) 1734-1744.

[135] Paape M.J., Miller R.H., Ziv G., Pharmacologic enhancement or suppression of phagocytosis by bovine neutrophils, Am. J. Vet. Res. 52 (1991) 363-366.

[136] Paape M.J., Lilius E.M., Wiitanen P.A., Kontio M.P., Miller R.H., Intramammary defense against infections induced by Escherichia coli in cows, Am. J. Vet. Res. 57 (1996) 477-482.

[137] Paape M.J., Rautiainen P.M., Lilius E.M., Malstrom C.E., Elsasser T.H., Development of anti-bovine TNF-alpha mAb and ELISA for quantitating TNF-alpha in milk after intramammary injection of endotoxin, $\mathrm{J}$. Dairy Sci. 85 (2002) 765-773.

[138] Pericle F., Liu J.H., Diaz J.I., Blanchard D.K., Wei S., Forni G., Djeu J.Y., Interleukin-2 prevention of apoptosis in human neutrophils, Eur. J. Immunol. 24 (1994) 440-444.
[139] Piccinini R., Bronzo V., Moroni P., Luzzago C., Zecconi A., Study on the relationship between milk immune factors and Staphylococcus aureus intramammary infections in dairy cows, J. Dairy Res. 66 (1999) 501510.

[140] Pongracz J., Webb P., Wang K., Deacon E., Lunn O.J., Lord J.M., Spontaneous neutrophil apoptosis involves caspase 3-mediated activation of protein kinase C-delta, J. Biol. Chem. 274 (1999) 37329-37334.

[141] Rainard P., Poutrel B., Effect of C5a and tumor necrosis factor-alpha on phagocytosis of Streptococcus agalactiae NT/X and IV/X by bovine neutrophils, Adv. Exp. Med. Biol. 418 (1997) 953-955.

[142] Rainard P., Sarradin P., Paape M.J., Poutrel B., Quantification of C5a/C5a(desArg) in bovine plasma, serum and milk, Vet. Res. 29 (1998) 73-88.

[143] Rainard P., Riollet C., Poutrel B., Paape M.J., Phagocytosis and killing of Staphylococcus aureus by bovine neutrophils after priming by tumor necrosis factor-alpha and the des-arginine derivative of C5a, Am. J. Vet. Res. 61 (2000) 951-959.

[144] Raj P.A., Karunakaran T., Sukumaran D.K., Synthesis, microbicidal activity, and solution structure of the dodecapeptide from bovine neutrophils, Biopolymers 53 (2000) 281-292.

[145] Rausch P.G., Moore T.G., Granule enzymes of polymorphonuclear neutrophils: A phylogenetic comparison, Blood 46 (1975) 913 919.

[146] Reed J.C., Mechanisms of apoptosis, Am. J. Pathol. 157 (2000) 1415-1430.

[147] Riollet C., Rainard P., Poutrel B., Differential induction of complement fragment C5a and inflammatory cytokines during intramammary infections with Escherichia coli and Staphylococcus aureus, Clin. Diagn. Lab. Immunol. 7 (2000) 161-167.

[148] Roy J.H., Factors affecting susceptibility of calves to disease, J. Dairy Sci. 63 (1980) 650-664.

[149] Salgar S.K., Paape M.J., Alston-Mills B., Miller R.H., Flow cytometric study of oxidative burst activity in bovine neutrophils, Am. J. Vet. Res. 52 (1991) 1201-1207.

[150] Salgar S.K., Paape M.J., Alston-Mills B., Peters R.R., Modulation of bovine neutrophil functions by monoclonal antibodies, Am. J. Vet. Res. 55 (1994) 227-233. 
[151] Santos-Beneit A.M., Mollinedo F., Expression of genes involved in initiation, regulation, and execution of apoptosis in human neutrophils and during neutrophil differentiation of HL-60 cells, J. Leukoc. Biol. 67 (2000) 712-724.

[152] Savill J.S., Wyllie A.H., Henson J.E., Walport M.J., Henson P.M., Haslett C., Macrophage phagocytosis of aging neutrophils in inflammation. Programmed cell death in the neutrophil leads to its recognition by macrophages, J. Clin. Invest. 83 (1989) 865-875.

[153] Savoini A., Marzari R., Dolzani L., Serrano D., Graziosi G., Gennaro R., Romeo D., Wide-spectrum antibiotic activity of bovine granulocyte polypeptides, Antimicrob. Agents Chemother. 26 (1984) 405-407.

[154] Schalm O.W., Lasmanis J., Carroll E.J., Effects of pre-existing leukocytosis on experimental coliform (Aerobacter aerogenes) mastitis in cattle, Am. J. Vet. Res. 25 (1964) 83-89.

[155] Schalm O.W., Lasmanis J., Carroll E.J., Significance of leukocytic infiltration into the milk in experimental Streptococcus agalactiae mastitis in cattle, Am. J. Vet. Res. 27 (1966) 1537-1546.

[156] Sipes K.M., Edens H.A., Kehrli M.E. Jr., Miettinen H.M., Cutler J.E., Jutila M.A., Quinn M.T., Analysis of surface antigen expression and host defense function in leukocytes from calves heterozygous or homozygous for bovine leukocyte adhesion deficiency, Am. J. Vet. Res. 60 (1999) $1255-1261$

[157] Sladek Z., Rysanek D., Apoptosis of polymorphonuclear leukocytes of the juvenile bovine mammary gland during induced influx, Vet. Res. 31 (2000) 553-563.

[158] Sladek Z., Rysanek D., Neutrophil apoptosis during the resolution of bovine mammary gland injury, Res. Vet. Sci. 70 (2001) 41-46.

[159] Sladek Z., Rysanek D., Faldyna M., Activation of phagocytes during initiation and resolution of mammary gland injury induced by lipopolysaccharide in heifers, Vet. Res. 33 (2002) 191-204.

[160] Slebodzinski A.B., Malinowski E., Lipczak W., Concentrations of triiodothyronine (T3), tumour necrosis factor-alpha (TNF-alpha) and interleukin-6 (IL-6) in milk from healthy and naturally infected quarters of cows, Res. Vet. Sci. 72 (2002) 17-21.

[161] Smits E., Cifrian E., Guidry A.J., Rainard P., Burvenich C., Paape M.J., Cell culture sys- tem for studying bovine neutrophil diapedesis, J. Dairy Sci. 79 (1996) 1353-1360.

[162] Smits E., Burvenich C., Guidry A.J., Roets E., In vitro expression of adhesion receptors and diapedesis by polymorphonuclear neutrophils during experimentally induced Streptococcus uberis mastitis, Infect. Immun. 66 (1998) 2529-2534.

[163] Smits E., Burvenich C., Guidry A.J., Heyneman R., Massart-Leen A., Diapedesis across mammary epithelium reduces phagocytic and oxidative burst of bovine neutrophils, Vet. Immunol. Immunopathol. 68 (1999) 169-176

[164] Smits E., Burvenich C., Guidry A.J., MassartLeen A., Adhesion receptor CD $11 \mathrm{~b} / \mathrm{CD} 18$ contributes to neutrophil diapedesis across the bovine blood-milk barrier, Vet. Immunol. Immunopathol. 73 (2000) 255-265.

[165] Sordillo L.M., Doymaz M.Z., Oliver S.P., Morphological study of chronic Staphylococcus aureus mastitis in the lactating bovine mammary gland, Res. Vet. Sci. 47 (1989) $247-252$.

[166] Sordillo L.M., Babiuk L.A., Modulation of bovine mammary neutrophil function during the periparturient period following in vitro exposure to recombinant bovine interferon gamma, Vet. Immunol. Immunopathol. 27 (1991) 393-402.

[167] Swain S.D., Jutila K.L., Quinn M.T., Cellsurface lactoferrin as a marker for degranulation of specific granules in bovine neutrophils, Am. J. Vet. Res. 61 (2000) 29-37.

[168] Sweeney J.F., Nguyen P.K., Omann G.M., Hinshaw D.B., Lipopolysaccharide protects polymorphonuclear leukocytes from apoptosis via tyrosine phosphorylation-dependent signal transduction pathways, J. Surg. Res. 74 (1998) 64-70.

[169] Taniguchi H., Yokomizo Y., Okuda K., FasFas ligand system mediates luteal cell death in bovine corpus luteum, Biol. Reprod. 66 (2002) 754-759

[170] Targowski S.P., Niemialtowski M., Appearance of $\mathrm{Fc}$ receptors on polymorphonuclear leukocytes after migration and their role in phagocytosis, Infect. Immun. 52 (1986) 798-802.

[171] Taub D.D., Oppenheim J.J., Review of the chemokine meeting the Third International Symposium of Chemotactic Cytokines, Cytokine 5 (1993) 175-179.

[172] Thornberry N.A., Lazebnik Y., Caspases: enemies within, Science 281 (1998) 1312 1316. 
[173] Tomita G.M., Wang Y., Paape M.J., Poultrel B., Rainard P., Influence of bispecific antibodies on the in vitro bactericidal activity of bovine neutrophils against Staphylococcus aureus, J. Dairy Sci. 83 (2000) 2269-2275.

[174] Valli V.E., Hulland T.J., McSherry B.J., Robinson G.A., Gilman J.P., The kinetics of haematopoiesis in the calf. I. An autoradiographical study of myelopoiesis in normal, anaemic and endotoxin treated calves, Res. Vet. Sci. 12 (1971) 535-550.

[175] Van Oostveldt K., Vangroenweghe F., Dosogne H., Burvenich C., Apoptosis and necrosis of blood and milk polymorphonuclear leukocytes in early and midlactating healthy cows, Vet. Res. 32 (2001) 617-622.

[176] Van Oostveldt K., Paape M.J., Dosogne H., Burvenich C., Effect of apoptosis on phagocytosis, respiratory burst and CD18 adhesion receptor expression of bovine neutrophils, Domest. Anim. Endocrinol. 22 (2002) 37-50.

[177] Van Oostveldt O.K., Paape M.J., Burvenich C., Apoptosis of bovine neutrophils following diapedesis through a monolayer of endothelial and mammary epithelial cells, J. Dairy Sci. 85 (2002) 139-147.

[178] Van Oostveldt O.K., Tomita G.M., Paape M.J., Capuco A.V., Burvenich C., Apoptosis of bovine neutrophils during mastitis experimentally induced with Escherichia coli or endotoxin, Am. J. Vet. Res. 63 (2002) 448453.

[179] Wang Y., Paape M.J., Leino L., Capuco A.V., Narva H., Functional and phenotypic characterization of monoclonal antibodies to bovine L-selectin, Am. J. Vet. Res. 58 (1997) 1392-1401.

[180] Wang Y., Zarlenga D.S., Paape M.J., Dahl G.E., Recombinant bovine soluble CD14 sensitizes the mammary gland to lipopolysaccharide, Vet. Immunol. Immunopathol. 86 (2002) 115-124.

[181] Ward P.A., Role of toxic oxygen products from phagocytic cells in tissue injury, Adv Shock Res. 10 (1983) 27-34.

[182] Watson R.W., Rotstein O.D., Nathens A.B., Parodo J., Marshall J.C., Neutrophil apoptosis is modulated by endothelial transmigration and adhesion molecule engagement, J. Immunol. 158 (1997) 945-953.

[183] Weber L., Peterhans E., Wyler R., The chemiluminescent response of bovine polymorphonuclear leucocytes isolated from milk and blood, Vet. Immunol. Immunopathol. 4 (1983) 397-412.

[184] Weber P.S., Madsen S.A., Smith G.W. Ireland J.J., Burton J.L., Pre-translational regulation of neutrophil L-selectin in glucocorticoid-challenged cattle, Vet. Immunol. Immunopathol. 83 (2001) 213-240.

[185] Weinmann P., Gaehtgens P., Walzog B., $\mathrm{Bcl}-\mathrm{Xl}$ - and Bax-alpha-mediated regulation of apoptosis of human neutrophils via caspase-3, Blood 93 (1999) 3106-3115.

[186] Worku M., Paape M.J., Marquardt W.W., Modulation of $\mathrm{Fc}$ receptors for $\mathrm{IgG}$ on bovine polymorphonuclear neutrophils by interferon-gamma through de novo RNA transcription and protein synthesis, Am. J. Vet. Res. 55 (1994) 234-238.

[187] Worku M., Paape M.J., Filep R., Miller R.H., Effect of in vitro and in vivo migration of bovine neutrophils on binding and expression of $\mathrm{Fc}$ receptors for $\mathrm{IgG} 2$ and $\mathrm{IgM}, \mathrm{Am}$. J. Vet. Res. 55 (1994) 221-226.

[188] Wright S.D., Ramos R.A., Tobias P.S. Ulevitch R.J., Mathison J.C., CD14, a receptor for complexes of lipopolysaccharide (LPS) and LPS binding protein, Science 249 (1990) 1431-1433.

[189] Yagi Y., Shiono H., Shibahara T., Chikayama Y., Nakamura I., Ohnuma A., Increase in apoptotic polymorphonuclear neutrophils in peripheral blood after intramammary infusion of Escherichia coli lipopolysaccharide, Vet. Immunol. Immunopathol. 89 (2002) 115-125.

[190] Yamashita K., Takahashi A., Kobayashi S., Hirata H., Mesner P.W. Jr., Kaufmann S.H., Yonehara S., Yamamoto K., Uchiyama T., Sasada M., Caspases mediate tumor necrosis factor-alpha-induced neutrophil apoptosis and downregulation of reactive oxygen production, Blood 93 (1999) 674-685.

[191] Yount N.Y., Yuan J., Tarver A., Castro T., Diamond G., Tran P.A., Levy J.N., McCullough C., Cullor J.S., Bevins C.L., Selsted M.E., Cloning and expression of bovine neutrophil beta-defensins. Biosynthetic profile during neutrophilic maturation and localization of mature peptide to novel cytoplasmic dense granules, J. Biol. Chem. 274 (1999) 26249-26258.

[192]Zhang G., Young J.R., Tregaskes C.A., Sopp P., Howard C.J., Identification of a novel class of mammalian Fc gamma receptor, J. Immunol. 155 (1995) 1534-1541. 